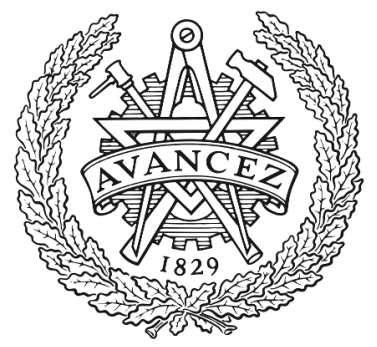

CHALMERS

UNIVERSITY OF TECHNOLOGY

\title{
Battery Loss and Stress Mitigation in a Cascaded H-Bridge Multilevel Inverter for Vehicle Traction Applications by Filter Capacitors
}

Downloaded from: https://research.chalmers.se, 2023-04-25 23:11 UTC

Citation for the original published paper (version of record):

Kersten, A., Josefsson, O., Grunditz, E. et al (2019). Battery Loss and Stress Mitigation in a Cascaded H-Bridge Multilevel Inverter for Vehicle

Traction Applications by Filter Capacitors. IEEE Transactions on Transportation Electrification, 5(3): 659-671. http://dx.doi.org/10.1109/TTE.2019.2921852

N.B. When citing this work, cite the original published paper.

(O2019 IEEE. Personal use of this material is permitted.

However, permission to reprint/republish this material for advertising or promotional purposes 


\title{
Battery Loss and Stress Mitigation in a Cascaded H-Bridge Multilevel Inverter for Vehicle Traction Applications by Filter Capacitors
}

\author{
Anton Kersten, Student Member, IEEE, Oskar Theliander, Emma Grunditz, \\ Torbjörn Thiringer, Senior Member, IEEE, and Massimo Bongiorno, Senior Member, IEEE
}

\begin{abstract}
In this paper, two types of filter capacitors of varying capacity, were connected to the battery packs of a cascaded H-Bridge single-star multilevel vehicle traction inverter, and their influence on the battery losses has been analyzed. The battery and capacitor simulation models used are experimentally verified in a down-scaled system. Different capacitor configurations were simulated for four drive cycle scenarios to determine the potentials for the mitigation of current pulse stresses and battery loss reduction with respect to the added weight. By adding capacitors corresponding to a weight of $4 \%$ of the initial battery storage, the peak current is reduced by $5 \%-20 \%$, depending on the operating point from $\mathrm{DC}$ to a few $\mathrm{kHz}$, and the battery losses are reduced by $10 \%$. In comparison, it is demonstrated that adding supercapacitors is more beneficial for lower output frequencies, while adding electrolytic capacitors is better for higher output frequencies. Furthermore, the low-order voltage harmonics of the DC-rails between the converter and battery were reduced by $10 \%-30 \%$ for frequencies above $9 \mathrm{kHz}$, which decreases the potential of electromagnetic disturbances. In addition, during cold battery temperatures, when it is very important to avoid heavy cyclings, the loss reduction using the capacitors was 2.5 times larger than for nominal temperature.
\end{abstract}

Index Terms-Cascaded, Efficiency, Electric vehicle, Electrolytic capacitor, H-bridge, Multilevel converter, Multilevel system, Supercapacitor.

\section{NOMENCLATURE}

CISPR Comité international spécial des perturbations radioélectriques

E-cap Electrolytic Capacitor

EMI Electromagnetic interference

EV Electric vehicle

FSHE Fundamental selective harmonic elimination

FTP75 EPA federal test procedure

HESS Hybrid electric storage system

HWFET Highway fuel economy test

MLI Multilevel inverter

MMC Modular multilevel converter

NEDC New european driving cycle

No Number

NPC Neutral point clamped

OP Operating point

PHEV Plug-in-hybrid electric vehicle

SS Small scale

The authors are with the Department of Electrical Engineering, Division of Electric Power Engineering, Chalmers University of Technology, Gothenburg, 41296 Sweden (e-mail: kersten@chalmers.se).

Manuscript received XX; revised XX.

\author{
US06 Supplemental federal test procedure \\ $C_{\text {Cap }} \quad$ Capacitance of filter capacitor \\ $\frac{C_{\text {Largescale }}}{C_{\mathrm{S} \text { mallscale }}}$ Capacity ratio between the systems \\ $C_{x}$ \\ $C_{x, \text { Bat }}$ \\ $h$ \\ $\hat{I}$ \\ $\hat{I}_{\text {Bat }}$ \\ $i_{\text {Bat }}$ \\ $i_{\text {Cap }}$ \\ $i_{\text {Cell }}$ \\ $i_{\mathrm{Cell}, \mathrm{a}_{j}}$ \\ $\frac{I_{\text {LargeScale }}}{I_{\text {Srescis }}}$ \\ $\overline{I_{\text {SmallScale }}}$ \\ $m$ \\ $n$ \\ $N_{\text {ser, Large }}$ \\ $\frac{N_{\text {ser, Large }}}{N_{\text {ser, Small }}}$ \\ $R_{0}$ \\ $R_{0, \text { Bat }}$ \\ $R_{\mathrm{ESR}}$ \\ $R_{x}$ \\ $R_{x, \text { Bat }}$ \\ $V_{\text {Bat }}$ \\ $V_{\text {Cell }}$ \\ $V_{\mathrm{DC}}$ \\ $\frac{V_{\text {LargeScale }}}{V_{\text {SmallScale }}}$ \\ $V_{\mathrm{OCV}}$ \\ $V_{\mathrm{OCV}, \mathrm{Bat}}$ \\ $\alpha_{j}$ \\ Transient cell capacitance with $\{1,2,3\} \in x$ \\ Transient battery capacitance with $\{1,2,3\} \in x$ \\ Harmonic order \\ Fundamental output current peak \\ Battery current peak \\ Battery current \\ Capacitor current \\ H-bridge cell current \\ Current of cell $j$ of phase a \\ with $\{1,2 \ldots, n\} \in j$ \\ Current ratio between the systems \\ Number of output levels \\ Number of H-bridge cells per phase \\ Ratio of series cells between the systems \\ Internal cell resistance \\ Internal battery resistance \\ Equivalent series resistance \\ Transient cell resistance with $\{1,2,3\} \in x$ \\ Transient battery resistance with $\{1,2,3\} \in x$ \\ Battery pack output voltage \\ Battery cell output voltage \\ Nominal module voltage \\ Voltage ratio between the systems \\ Battery cell open circuit voltage \\ Battery pack open circuit voltage \\ Switching angle with $\{1,2 \ldots, n\} \in j$
}

\section{INTRODUCTION}

$\mathbf{F}$ OR traction applications, as in electrified vehicles (EVs), it is of utmost importance to have a high efficiency in order to minimize the necessary cooling, as well as to be able to utilize the amount of charge in the battery as much as possible. A reduced cooling effort results in an increased inverter power density and, consequently, a lighter vehicle weight. Conventionally, a two-level inverter is utilized as the vehicle traction converter, though in [1]-[4] the advantages and disadvantages of multilevel inverters (MLI) for EVs are analyzed. In these articles the single-star cascaded H-bridge inverter is evaluated. With this structure, the inverter achieves 
reduced inverter losses as well as allows for a reduced EMI. For the operation of the inverter, different control strategies can be found in [5]-[8], using a reduced switching frequency, down to fundamental frequency. In [9]-[11] a multilevel inverter system with fundamental selective harmonic elimination, reducing the RMS-current, is proposed as a suitable control strategy. A major drawback of this topology is that it might increase the battery losses, since it stresses the battery packs with strong current pulses ranging from DC up to $1 \mathrm{kHz}$ [12]. It has been discussed whether these current pulses cause an additional rapid aging of the battery cells, but this controversy has been proven wrong, except for the increased RMS current [13], [14].

\section{A. Literature Review}

Several investigations regarding the efficiency, low voltage output harmonics and fault tolerance of multilevel tractioninverters can be found in [15]-[19], but missing in the available literature is the consideration and quantification of the battery losses. An H-bridge has always a capacitor connected between the two DC-link rails to stabilize the DC-link and to reduce the drawn battery RMS current. The same is true for two-level inverters, which are predominant in the powertrain of modern vehicles. Several investigations of two-level traction inverters show that a Hybrid Electric Storage System (HESS) of a battery pack and a supercapacitor can be an effective means to increase the power density of the storage and, thus, achieve an improved battery efficiency [20]-[22], especially for low voltage hybrid vehicles as in [23]. Additionally, the hybrid storage prolongs the lifetime of the battery, but missing in the available investigations is the relation of the reduced battery losses and the additional system costs. Since, the voltage sources in a multilevel inverter are exposed to mediumfrequency current stresses, it is also beneficial to employ additional high power storages as electrolytic capacitors as well as supercapacitors in order to reduce the loss and current stress. Therefore, [24] and [25] show different approaches for the application of supercapacitors for an NPC and an MMC multilevel traction inverter, but a common DC-link is used and the capacitors thus require a voltage balancing algorithm. Placing several battery packages directly into the module, as suggested in [26]-[28], provides an intrinsic safety regarding the battery pack voltage level [29], [30]. However, the topic of HESS directly employed in the modules for traction applications is not covered yet. Another benefit with extra capacitors is also that the low-frequency EMI emitted from the negative and positive DC-link rails and cables, is reduced [31], since the lower EMI limit for conducted noise according to the Chinese standard [32] is $9 \mathrm{kHz}$. Therefore, the applied supercapacitors would act as a differential mode filter for low frequency harmonics. In comparison, the standard CISPR 25 [33] regulates disturbances beginning from $150 \mathrm{kHz}$ and up to $30 \mathrm{MHz}$. Also, for a cold battery, it is important to avoid heavy cyclings of the battery cells, since the internal impedance increases by a multiple [34]. Thus, the life time loss, due to the power dissipation is substantial as the temperature goes to $0{ }^{\circ} \mathrm{C}$ or below [35], [36].

\section{B. Key Contributions}

The concept of using cascaded H-bridges equipped with parts of the battery and capacitors to form an HESS, and in this way to eliminate the traditional two-level propulsion inverter completely for an electrified vehicle, is a very new topic. The issue of how relieving capacitors could assist the battery cells to form a unit with higher power density as well as reduced EMI has yet to be covered. Therefore, the contribution of this paper is that it demonstrates a new concept, a vehicle converter equipped with combinations of battery cells and capacitors to form a unit with increased power density and lowered EMI. Electrolytic capacitors as well as supercapacitors are used to reduce stress and losses that medium-frequency current pulsations cause in a vehicle's battery packs with a multilevel inverter setup. Further, the reduction of current harmonics with respect to capacitor type and capacitance and the battery loss reduction with respect to the added weight and systems costs are quantified using simulations and experiments.

\section{Paper Organization}

The remainder of this paper is divided into six sections as follows: In Section II, an example powertrain is modeled, the control of the converter is described and the battery loss modeling including filter capacitors is explained. Section III shows the small scale lab setup used to prove the validity of concept. Section IV deals with the reduction of the low-order battery current harmonics, followed by a drive cycle analysis in Section V and a cold climate performance investigation in Section VI. Finally, conclusions are presented in Section VII.

\section{DRive Train Modeling ANd Control}

A plug-in hybrid electric vehicle (PHEV) with a $50 \mathrm{~km}$ electric driving range is considered as the reference system. Instead of utilizing a common two-level inverter, a cascaded $\mathrm{H}$-bridge multilevel inverter is used. To be able to determine the influence of the filter capacitors, connected to the battery packs of the H-bridges in a multilevel inverter, a drive train is designed and parametrized. It should be mentioned that there are always capacitors attached to an $\mathrm{H}$-bridge to facilitate the high-frequency switched current, but here the amount of capacitance is increased to filter out the low-order current harmonics produced by the inverter. The analyzed drive system is a 7-level cascaded multilevel inverter consisting of H-bridge modules, as can be seen in Fig. 1(a) and 1(b). The system comprises $9 \mathrm{H}$-bridges connected into 3 branches with $3 \mathrm{H}$-bridges in series for each phase. Every H-bridge has a separate energy storage connected to its DC side. By controlling the switches in the $\mathrm{H}$-bridge in different ways, one bridge can create an output voltage equal to $V_{\mathrm{DC}_{\mathrm{ML}}},-V_{\mathrm{DC}_{\mathrm{ML}}}, 0 \mathrm{~V}$ and open circuit at its terminals, where $V_{\mathrm{DC}_{\mathrm{ML}}}$ is the input voltage of each $\mathrm{H}$ bridge. Assuming the voltage sources are equal, the number of levels per phase that can be created are equal to

$$
2 n+1,
$$

where $n$ equals the number of full-bridge modules per phase.

The modeled vehicle should resemble a small passenger car as in [37], which is propelled by an interior permanent 


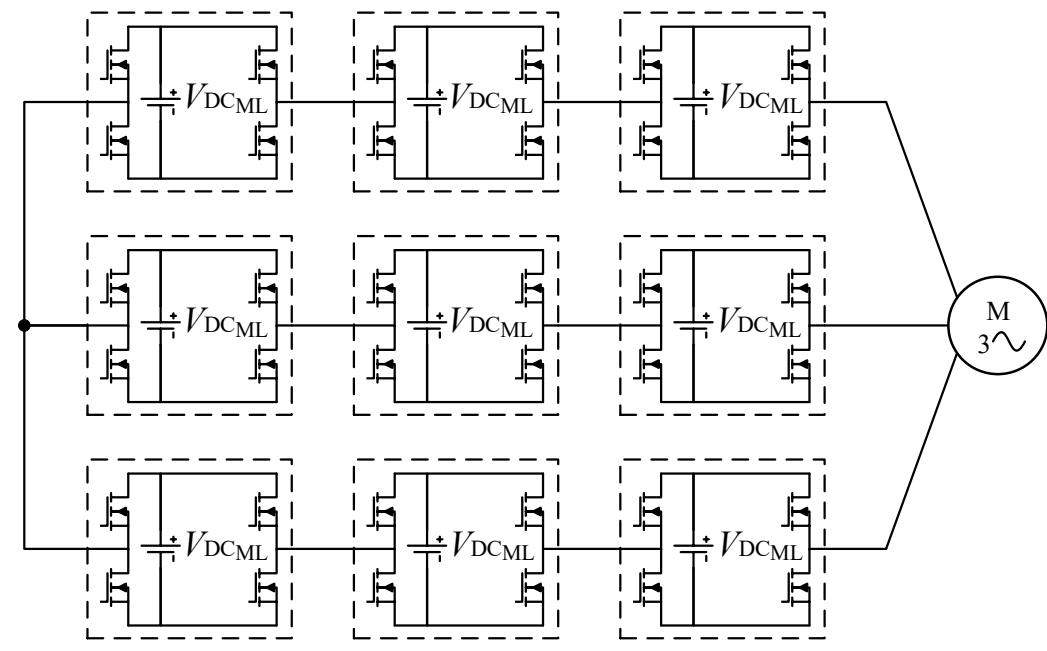

(a)

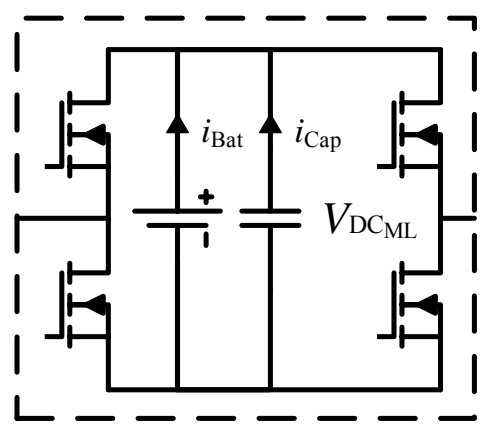

(b)

Fig. 1: Overview of (a) the analyzed 7-level cascaded H-bridge multilevel inverter and (b) one single H-bridge cell equipped with a capacitor.

TABLE I: Drive-train parameters

(a) Vehicle

\begin{tabular}{lcc}
\hline & Value & Unit \\
\hline Vehicle mass $m_{\text {veh }}$ & 1025 & $\mathrm{~kg}$ \\
Occupant weight $m_{\text {occ }}$ & 75 & $\mathrm{~kg}$ \\
Frontal area $A$ & 2.2 & $\mathrm{~m}^{2}$ \\
Drag cofficient $C_{\mathrm{d}}$ & 0.205 & \\
Rolling resistance $C_{\mathrm{r}}$ & 0.01 & \\
Wheel radius $r_{\text {wheel }}$ & 0.33 & $\mathrm{~m}$ \\
Gear box ratio $G_{\mathrm{r}}$ & 11.5 & \\
Gearbox efficiency $\eta_{\mathrm{G}}$ & 90 & $\%$ \\
Top speed $v_{\max }$ & 130 & $\mathrm{~km} / \mathrm{h}$ \\
\hline
\end{tabular}

(b) Motor-PMSM

\begin{tabular}{lcc}
\hline & Value & Unit \\
\hline Stator resistance $R_{\mathrm{s}}$ & 20 & $\mathrm{~m} \Omega$ \\
D-axis inductance $L_{\mathrm{d}}$ & 150 & $\mu \mathrm{H}$ \\
Q-axis inductance $L_{\mathrm{q}}$ & 300 & $\mu \mathrm{H}$ \\
Flux constant $\psi_{\mathrm{m}}$ & 33 & $\mathrm{mWb}$ \\
Pole pairs $n_{\mathrm{p}}$ & 5 & \\
Max torque $T_{\max }$ & 109 & $\mathrm{~N} \mathrm{~m}$ \\
phase current $I_{\mathrm{RMS}}$ & 212 & $\mathrm{~A}$ \\
phase voltage $\hat{V}_{\mathrm{pk}}$ & 150 & $\mathrm{~V}$ \\
Max speed $n$ & 12000 & $\mathrm{rpm}$ \\
\hline
\end{tabular}

magnet machine. The vehicle and motor parameters are shown in TABLE I(a) and $\mathrm{I}(\mathrm{b})$, respectively. The operating points of the vehicle and inverter can be calculated according to [38]. The electric machine has a power rating of about $50 \mathrm{~kW}$.

\section{A. Battery Model}

To supply the voltage to the H-bridge cells of the multilevel inverter (MLI), 9 battery packs are used, building up a total capacity of $10 \mathrm{kWh}$. Each battery pack consists of 150 cells, 10 in parallel and 15 in series. In this way a

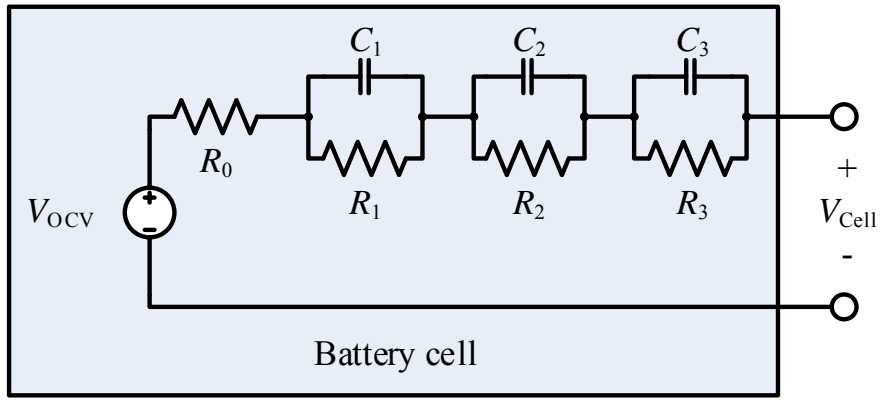

Fig. 2: Three-time-constant Randles model of a battery cell.

nominal battery pack voltage of about $50 \mathrm{~V}$ and a capacity of $23 \mathrm{Ah}$ is achieved. Power-optimized, cylindrical 26650 battery cells (ANR26650M1A [39]) with a $\mathrm{LiFePO}_{4}$ chemistry of the manufacturer A123 Systems are chosen. Each cell has a nominal capacity and voltage of about $2300 \mathrm{mAh}$ and $3.3 \mathrm{~V}$, respectively, with a maximum output current of $70 \mathrm{~A}$. For normal operation, it is assumed that the ambient battery temperature is about $25^{\circ} \mathrm{C}$, whereas for cold climate conditions the temperature is below $0^{\circ} \mathrm{C}$. The electric behaviour of the battery cells is modeled using the Randles model [40]-[42] and up to three series RC-elements are applied, as depicted in Fig. 2. Here, the resistances $R_{1}$ to $R_{3}$ and the capacitances $C_{1}$ to $C_{3}$ describe the dynamic performance of the battery cell. The resistance $R_{0}$ is the internal cell resistance and the voltage source $V_{\mathrm{OCV}}$ represents the open circuit voltage, which is dependent on the SOC. Since the considered frequency range is in the range of a few $\mathrm{kHz}$ and below, the battery inductance is assumed to be negligible in the further analysis and it is, therefore, not depicted in the scheme of the battery cell model [41], [43]. In an experimental setup, a pulsed current with an amplitude of $28 \mathrm{~A}$ and a frequency of $1 \mathrm{~Hz}$ was applied to extract the cell parameters [44]. With the help of the monitored cell and open circuit voltages, as well 
TABLE II: Battery cell parameters

\begin{tabular}{lrrrrrrrr}
\hline Measurement: & $\mathrm{R} 0[\mathrm{~m} \Omega]$ & $\mathrm{R} 1[\mathrm{~m} \Omega]$ & $\mathrm{R} 2[\mathrm{~m} \Omega]$ & $\mathrm{R} 3[\mathrm{~m} \Omega]$ & $\mathrm{C} 1[\mathrm{~F}]$ & $\mathrm{C} 2[\mathrm{~F}]$ & $\mathrm{C} 3[\mathrm{~F}]$ & Fit [\%] \\
\hline $3.23 \mathrm{~V} 1 \mathrm{~Hz} 28 \mathrm{~A}$ & 10.02 & 2.47 & 1.41 & 1.37 & 0.49 & 9.93 & 168.94 & 99.49 \\
\hline
\end{tabular}

TABLE III: Battery configuration per H-bridge

\begin{tabular}{lcc}
\hline & Value & Unit \\
\hline No. of cells in series & 15 & \\
No. of cells in parallel & 10 & \\
DC-resistance & 22.9 & $\mathrm{~m} \Omega$ \\
Weight & 12.5 & $\mathrm{~kg}$ \\
Volume & 5.28 & $\mathrm{~L}$ \\
\hline
\end{tabular}

TABLE IV: Capacitor configurations, values per H-bridge

\begin{tabular}{|c|c|c|c|c|c|c|c|}
\hline Config. & Color & Type & $C[\mathrm{mF}]$ & $R[\mathrm{~m} \Omega]$ & {$[\mathrm{kg}]$} & $V[\mathrm{~L}]$ & $\rho\left[\mathrm{Whkg}^{-1}\right]$ \\
\hline 0 & & N/A & - & - & - & - & - \\
\hline 1 & & E-cap & 5.87 & 52.5 & 0.55 & 0.37 & 0.0036 \\
\hline 2 & & E-cap & 23.5 & 13.1 & 2.2 & 1.5 & 0.0036 \\
\hline 3 & & E-cap & 41.1 & 7.5 & 3.9 & 2.6 & 0.0036 \\
\hline 4 & & E-cap & 58.7 & 5.25 & 5.5 & 3.7 & 0.0036 \\
\hline 5 & & Supercap & 4440 & 104 & 0.46 & 0.36 & 3.28 \\
\hline 6 & & Supercap & 17800 & 25.9 & 1.8 & 1.4 & 3.28 \\
\hline 7 & & Supercap & 31100 & 14.8 & 3.2 & 2.5 & 3.28 \\
\hline 8 & & Supercap & 44400 & 10.4 & 4.6 & 3.6 & 3.28 \\
\hline
\end{tabular}

as the battery current, the battery cell parameters could be numerically determined, as shown in TABLE II. For the full scale system, the battery pack's parameters for each H-bridge are described in TABLE III.

\section{B. Filter Capacitors}

Each battery pack is equipped with an additional capacitor, which is modeled as a series RC-element connected in parallel. Since the considered frequency range up to a few $\mathrm{kHz}$ is sufficient for the determination of the losses, the series inductance or additional parasitic elements can be neglected. Two different capacitors types, electrolytic and super capacitors, of various capacity, as shown in TABLE IV, are considered for the analysis. These are compared to the standard solution without filter capacitors (Configuration 0). It should be noted that the electrolytic configurations (configuration 1-4) have about the same weight and volume as the corresponding super capacitance configurations (configuration 5-8).

\section{Control - Fundamental Selective Harmonic Elimination}

Space vector modulation or carrier based PWM are common approaches to operate a multilevel inverter [45]-[47]. These methods work properly over a wide speed range, whereas fundamental switching techniques offer a high inverter efficiency at high speeds and nominal output voltage. Therefore, the 7-level inverter is controlled by Fundamental Selective

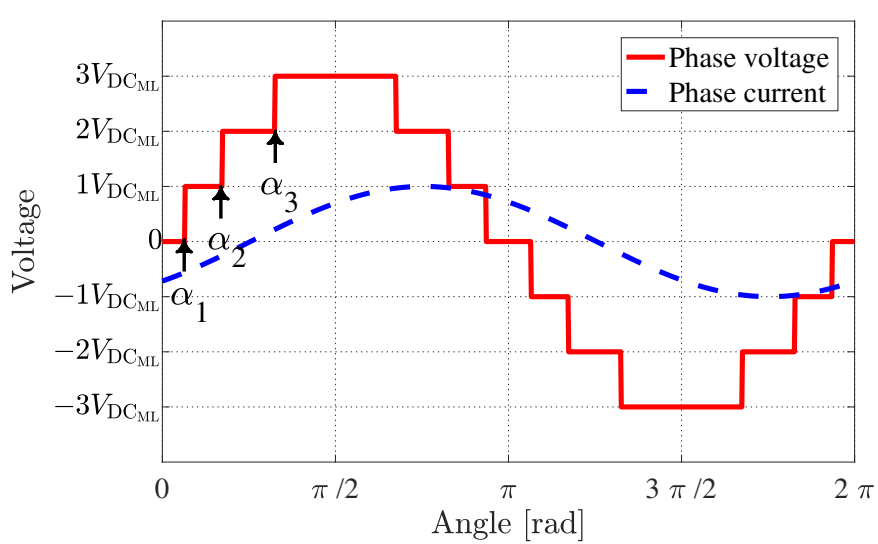

(a)

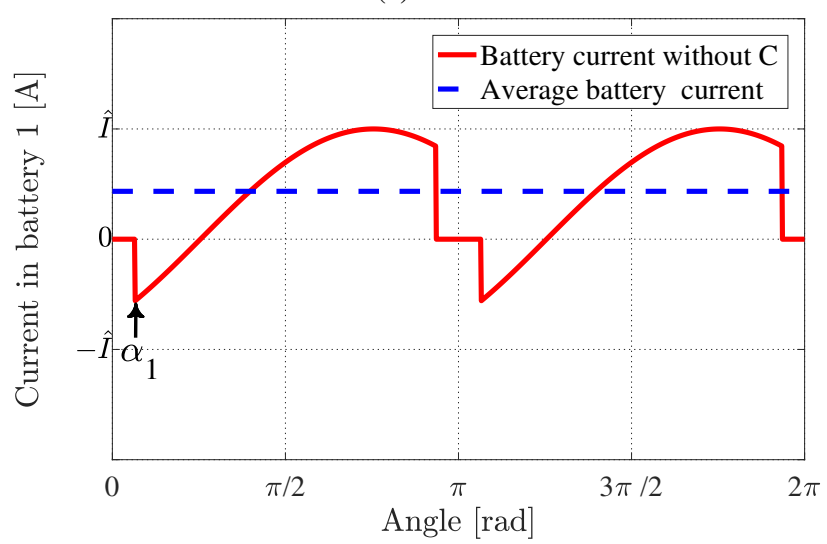

(b)

Fig. 3: Waveforms: (a) phase current and voltage. (b) battery current in cell number 1 .

Harmonic Elimination (FSHE) [10], [11] in order to create the desired three phase voltages with acceptable low-order harmonic content. By being able to choose the sequence of turn on/off time instants for the different H-bridges in the multilevel inverter, the amplitude of the fundamental frequency as well as a selection of low-order harmonics in the inverters's output voltage can be controlled. For an m-level inverter, the amplitude of the fundamental frequency and $\frac{m-3}{2}$ number of harmonics can be controlled. Since the motor inductance acts as a current low pass filter, it is of utmost importance to minimize the low frequency voltage harmonics. The voltage waveform built up by the 7-level inverter can be seen in Fig. 3(a). The angles $\alpha_{1}, \alpha_{2}$ and $\alpha_{3}$ describe the instants when H-bridge 1-3 should be activated. According to [10], [11], the fourier series expansion of the signal for the different harmonics, $h$, can be written as

$$
V_{h_{\mathrm{ML}}}=\frac{4 V_{\mathrm{DC}}}{h \pi}\left(\cos \left(h \alpha_{1}\right)+\cos \left(h \alpha_{2}\right)+\cos \left(h \alpha_{3}\right)\right)
$$


when assuming the DC-voltages are equal for all H-bridges. The resulting battery current in comparison to the average current is exemplified in Fig. 3(b). It is far from a DC quantity. Within this analysis, the voltage harmonics of the 5 th and 7 th order are set to be zero. Equation (2) can be used to calculate the switching angles for different amplitudes of the fundamental output voltage. At a low modulation index (below 0.487), the simultaneous control over both harmonics cannot be fully achieved, but they are instead minimized with a prioritization on the 5th harmonic. For high modulation indices (up to 1.07), the 5th and 7th harmonic can easily be eliminated [9]. To keep the battery packs balanced during motor operation, the controller makes sure to use the battery with the highest and lowest voltage to the largest and smallest extent, respectively. The maximum output voltage the inverter can create with a DC-link margin of $10 \%$ to account for the voltage drops and the needed blanking time of the inverter valves, as well as to have a sufficient control margin, can be expressed as

$$
V_{\text {phase }_{\mathrm{RMS}, \mathrm{MAx}}}=0.9 \cdot 1.07 \frac{V_{\mathrm{DC}_{\mathrm{ML}}} \cdot n}{\sqrt{2}},
$$

where $V_{\mathrm{DC}}$ describes the input voltage of an $\mathrm{H}$-bridge unit. For this analysis the vehicle does not incorporate regenerative breaking, since it simplifies the control of the machine, while the relative difference between various results is not affected [37].

\section{Modeling Battery Losses}

The battery losses, dealt with in this paper, are the ohmic/joule losses. As shown in Fig. 3(b), the H-bridge modules of the inverter are stressed with a chopped sinusoidal current profile, containing a band of low-order harmonics. For example, Fig. 4 depicts the Fourier analysis of the current shape seen in Fig. 3(b). It can be seen, that the second harmonic is even larger than the DC component. Therefore, the low-order harmonic components should be filtered out by paralleled filter capacitors. Depending on the frequency, the various current components are distributedly conducted through the impedance network of the battery-pack and the parallel filter capacitor, as schematically depicted in Fig. 5 [40], [43], [48]. Thus, ohmic losses are caused in the equivalent series resistance $\left(R_{\mathrm{ESR}}\right)$ of the capacitor [49] and in the battery pack's resistances $\left(R_{0, \text { Bat }}\right.$ to $\left.R_{3, \mathrm{Bat}}\right)$ [41], which are equally considered as the battery or energy storage losses. To analytically determine the battery losses is not readily done, since the H-bridge cells are stressed with a current, that is neither a DC nor a pure sinusoidal quantity, containing numerous low-order harmonic components. However, using simulation tools, can largely resolve this issue. For this purpose, just the impedance network needs to be modeled and the current source must be programmed according to the operating point and the number of the H-bridge module. As for example, the current profile of the $\mathrm{H}$-bridge can be derived, beginning from the three phase output currents

$$
i_{\mathrm{abc}}=\hat{I} \sin (\omega t-k \cdot 120-\varphi) \quad \text { with }\{0,1,2\} \in k \quad,
$$

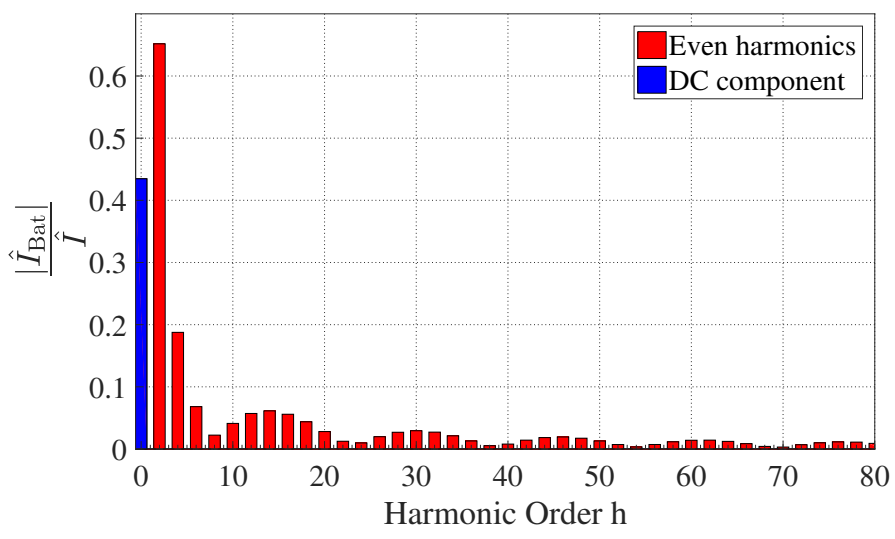

Fig. 4: Frequency spectrum of the drawn battery current shown in Fig.3(b).

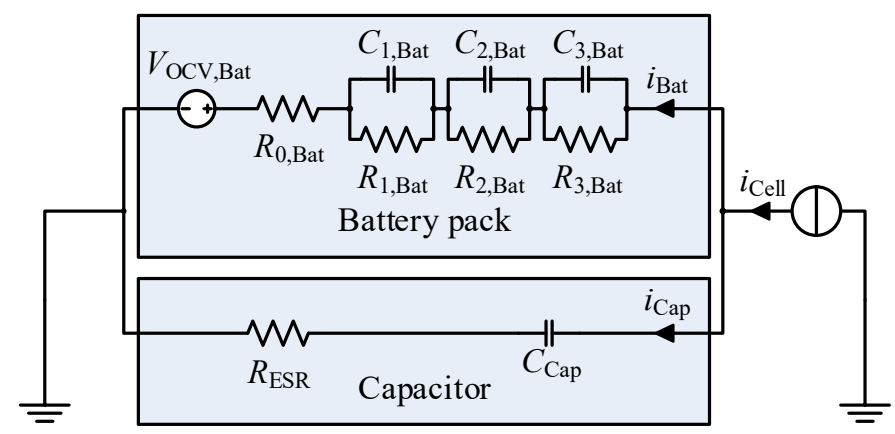

Fig. 5: Impedance network of the battery pack and the parallel capacitor to determine the battery losses.

where $k$ accounts for the phase shift among the phases and $\varphi$ is the power factor of the corresponding operating point. Thus, if focusing on just one phase, the current in phase a is

$$
i_{\mathrm{a}}=\hat{I} \sin (\omega t-\varphi) \text {. }
$$

Due to the cascaded H-bridge topology and the used FSHE control, each H-bridge cell is stressed with a chopped sinusoidal current as

$$
i_{\mathrm{Cell}_{\mathrm{a}} \mathrm{a}}= \begin{cases}+i_{\mathrm{a}}, & \text { if } \alpha_{j} \leq \omega t \leq \pi-\alpha_{j} \\ -i_{\mathrm{a}}, & \text { if } \pi+\alpha_{j} \leq \omega t \leq 2 \pi-\alpha_{j} \\ 0, & \text { else }\end{cases}
$$

where $j$ equals the number of the corresponding H-bridge cells as $j=\{1,2, \ldots, n\}$.

\section{Small Scale Lab Setup}

To verify the theory assumptions and to demonstrate the validity of concept, a small scale system is built, shown in Fig. 6. The H-bridges' battery packs consist of 4 in series connected battery cells, which gives a nominal voltage of $13.2 \mathrm{~V}$ and a total capacity of $270 \mathrm{Wh}$. This results in a voltage ratio of the large and small scale system as

$$
\frac{V_{\text {LargeScale }}}{V_{\text {SmallScale }}}=\frac{N_{\text {ser,Large }}}{N_{\text {ser,Small }}}=\frac{50.0 \mathrm{~V}}{13.2 \mathrm{~V}} \approx 3.8
$$




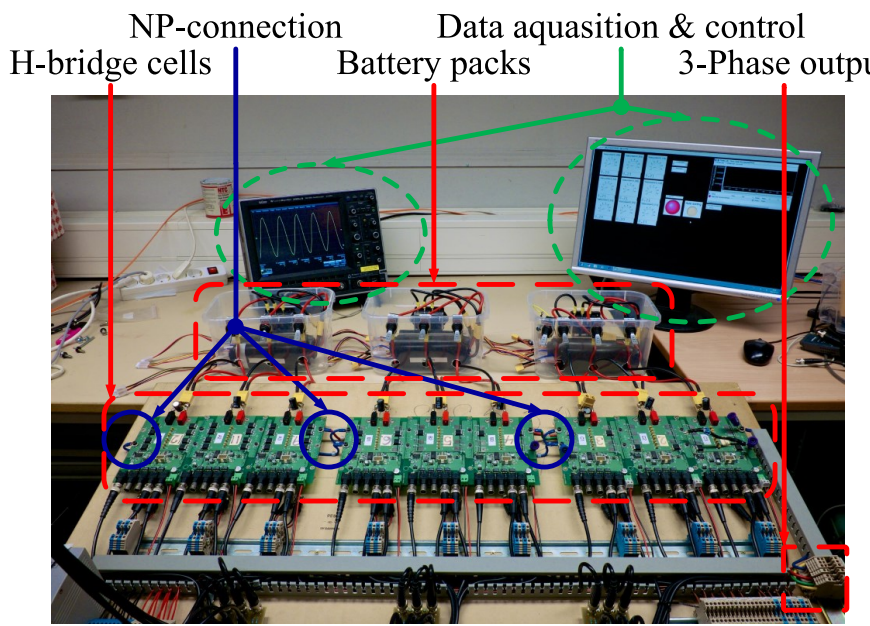

Fig. 6: Lab setup according to small scale ratios.

TABLE V: Small scale capacitor configurations, values per H-bridge

\begin{tabular}{|c|c|c|c|c|c|c|c|}
\hline \multicolumn{2}{|c|}{ Config. Color } & \multirow{2}{*}{$\begin{array}{l}\text { Type } \\
\text { N/A }\end{array}$} & \multicolumn{5}{|c|}{$C[\mathrm{mF}] R[\mathrm{~m} \Omega] m[\mathrm{~kg}] V[\mathrm{~L}] \rho\left[\mathrm{Whkg}^{-1}\right]$} \\
\hline $0_{S S}$ & & & - & - & - & - & - \\
\hline $4_{S S}$ & & E-cap & 22 & 14 & 0.14 & 0.098 & 0.0038 \\
\hline $8 S S$ & & Supercap & 16700 & 27.6 & 0.12 & 0.094 & 3.37 \\
\hline
\end{tabular}

and a current ratio as

$$
\begin{aligned}
\frac{C_{\text {LargeScale }}}{C_{\text {SmallScale }}}=\frac{10 \mathrm{kWh}}{0.27 \mathrm{kWh}}=\frac{I_{\text {LargeScale }} V_{\text {LargeScale }}}{I_{\text {SmallScale }} V_{\text {SmallScale }}} \\
\frac{I_{\text {LargeScale }}}{I_{\text {SmallScale }}} \approx 9.7 .
\end{aligned}
$$

For verification purposes, configuration 0 , configuration 4 and configuration 8 are scaled down to fit the small scale system, so that the specific energy in $\mathrm{Whkg}^{-1}$ of both systems are equal. The small scale capacitor configurations are shown in TABLE V.

\section{A. Operating Points}

A passenger vehicle operates over a wide range of torque and speed, resulting in a broad speed-torque region of the electric drive train [50]. In order to determine the actual drive train losses, a limited number of representative operating points of an electrified vehicle are considered. Therefore, a detailed analysis of the drive train was performed at six different operating points taken from chapter 4 in [37]. The inverter operating points for this small passenger vehicle are shown in Fig. 7. The six selected operating points are depicted with white dots and can additionally be found in TABLE VI. To get the equivalent operating points of the small scale system, the large scale operating points are converted according to (7) and (9), with the result shown in TABLE VII.

\section{B. Experimental Model Verification}

Before determining the battery performance for the chosen six operating points, presented in TABLE VII, the battery and
TABLE VI: Analyzed operating points for the vehicle according to [37]

\begin{tabular}{cccrcrc}
\hline OP No: & \multicolumn{1}{c}{ Speed } & $\mathrm{T}$ & \multicolumn{1}{c}{$I_{\mathrm{RMS}}$} & $V_{\text {phase }}$ & $\varphi$ & $\mathrm{f}$ \\
\hline 1 & $1000 \mathrm{RPM}$ & $30 \mathrm{Nm}$ & $78 \mathrm{~A}_{\mathrm{RMS}}$ & $17 \mathrm{~V}_{\mathrm{RMS}}$ & $25^{\circ}$ & $83 \mathrm{~Hz}$ \\
2 & $1000 \mathrm{RPM}$ & $60 \mathrm{Nm}$ & $137 \mathrm{~A}_{\mathrm{RMS}}$ & $22 \mathrm{~V}_{\mathrm{RMS}}$ & $36^{\circ}$ & $83 \mathrm{~Hz}$ \\
3 & $1000 \mathrm{RPM}$ & $90 \mathrm{Nm}$ & $185 \mathrm{~A}_{\mathrm{RMS}}$ & $28 \mathrm{~V}_{\mathrm{RMS}}$ & $42^{\circ}$ & $83 \mathrm{~Hz}$ \\
4 & $5000 \mathrm{RPM}$ & $30 \mathrm{Nm}$ & $78 \mathrm{~A}_{\mathrm{RMS}}$ & $77 \mathrm{~V}_{\mathrm{RMS}}$ & $27^{\circ}$ & $417 \mathrm{~Hz}$ \\
5 & $5000 \mathrm{RPM}$ & $60 \mathrm{Nm}$ & $137 \mathrm{~A}_{\mathrm{RMS}}$ & $103 \mathrm{~V}_{\mathrm{RMS}}$ & $40^{\circ}$ & $417 \mathrm{~Hz}$ \\
6 & $10000 \mathrm{RPM}$ & $30 \mathrm{Nm}$ & $101 \mathrm{~A}_{\mathrm{RMS}}$ & $106 \mathrm{~V}_{\mathrm{RMS}}$ & $1^{\circ}$ & $833 \mathrm{~Hz}$ \\
\hline
\end{tabular}

TABLE VII: Analyzed operating points for the small scale lab setup

\begin{tabular}{crcrccc}
\hline OP No: & \multicolumn{1}{c}{ Speed } & $\mathrm{T}$ & \multicolumn{1}{c}{$I_{\mathrm{RMS}}$} & $V_{\text {phase }}$ & $\varphi$ & $\mathrm{f}$ \\
\hline 1 & $1000 \mathrm{RPM}$ & $-\mathrm{Nm}$ & $8 \mathrm{~A}_{\mathrm{RMS}}$ & $4 \mathrm{~V}_{\mathrm{RMS}}$ & $25^{\circ}$ & $83 \mathrm{~Hz}$ \\
2 & $1000 \mathrm{RPM}$ & $-\mathrm{Nm}$ & $14 \mathrm{~A}_{\mathrm{RMS}}$ & $6 \mathrm{~V}_{\mathrm{RMS}}$ & $36^{\circ}$ & $83 \mathrm{~Hz}$ \\
3 & $1000 \mathrm{RPM}$ & $-\mathrm{Nm}$ & $19 \mathrm{~A}_{\mathrm{RMS}}$ & $7 \mathrm{~V}_{\mathrm{RMS}}$ & $42^{\circ}$ & $83 \mathrm{~Hz}$ \\
4 & $5000 \mathrm{RPM}$ & $-\mathrm{Nm}$ & $8 \mathrm{~A}_{\mathrm{RMS}}$ & $20 \mathrm{~V}_{\mathrm{RMS}}$ & $27^{\circ}$ & $417 \mathrm{~Hz}$ \\
5 & $5000 \mathrm{RPM}$ & $-\mathrm{Nm}$ & $14 \mathrm{~A}_{\mathrm{RMS}}$ & $27 \mathrm{~V}_{\mathrm{RMS}}$ & $40^{\circ}$ & $417 \mathrm{~Hz}$ \\
6 & $10000 \mathrm{RPM}$ & $-\mathrm{Nm}$ & $10 \mathrm{~A}_{\mathrm{RMS}}$ & $28 \mathrm{~V}_{\mathrm{RMS}}$ & $1^{\circ}$ & $833 \mathrm{~Hz}$ \\
\hline
\end{tabular}

capacitor models need to be experimentally verified, using the small scale system. The voltage drop and current are sampled, while applying a current step to the H-Bridge. The measured and simulated waveforms for the small scale configurations for a current step of about $16 \mathrm{~A}$ are shown in Fig. 8. The waveforms agree very well between the simulations and the measurements for each configuration. Almost the same current was used for the three measurements. The highest voltage drop is observed without the capacitances (configuration $0_{S S}$ ), while the electrolytic capacitance holds the voltage very well in the beginning of the pulse due to its low resistance. Since the electrolytic capacitor does not have a high capacitance, the voltage drop starts to increase quite quickly at the low frequency that operating point 1 has. The supercapacitor configuration $\left(8_{S S}\right)$ shows a slightly different behaviour, since it has a higher resistance and more capacitance. It has a higher voltage drop in the beginning of the pulse compared to the electrolytic configuration, but it holds this voltage drop, since the capacitance is very high. The product of the voltage drop and the battery current yields the battery losses, so that the simulated and measured battery losses can easily be compared with each other. The open circuit voltage $V_{\mathrm{OCV}}$ of the battery was estimated using a Kalman filter. The compliance of measurement and simulation results of the battery losses for the six operating points for the configurations $0_{S S}, 4_{S S}$ and $8_{S S}$ are presented in TABLE VIII. As shown in Fig. 8, there are some small discrepancies, but the simulations agree well with the measurements, with only a few percent discrepancy. Therefore, the voltage-current relation of the battery simulations could be verified by the measurement. The battery losses can be determined in simulation by the current and impedance network of the battery model and the 


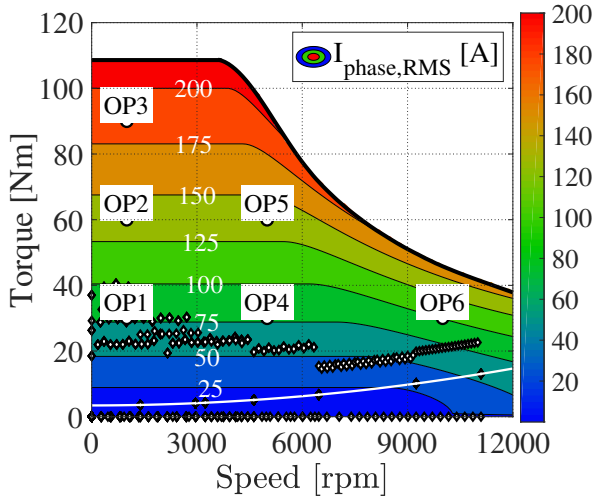

(a) RMS-value of the phase currents

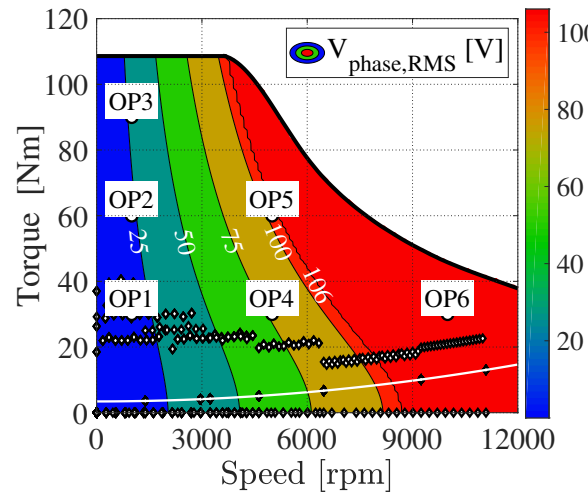

(b) RMS-value of phase voltages

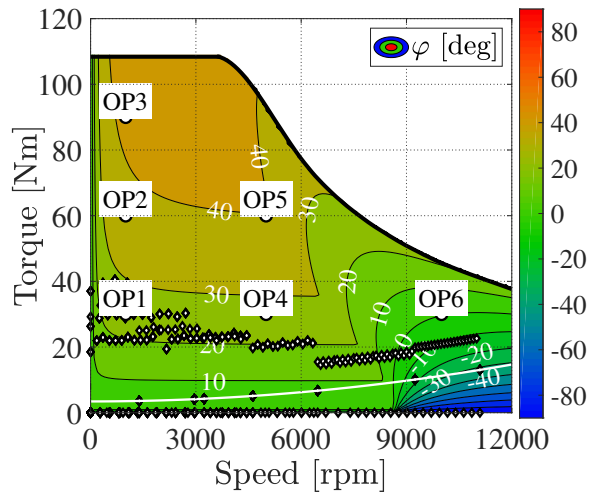

(c) Power factor angle

Fig. 7: Inverter operating points when using an electric vehicle with the electrical machine in TABLE I. The NEDC is marked with diamonds as a reference, while the white line shows the torque needed to propel the vehicle at constant speed. Circles mark the six analyzed operating points.

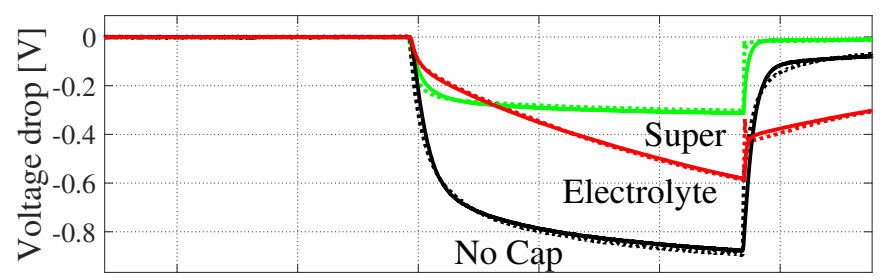

...... Config. 0ss meas. …...Config. 4ss meas. ..... Config. 8ss meas. —Config. 0ss model —Config. 4ss model — Config. 8ss mode

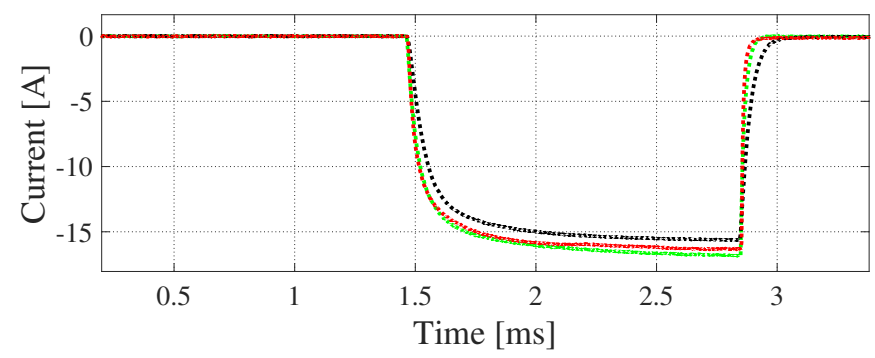

Fig. 8: Verification of the model in the small scale system using a current step.

TABLE VIII: Loss verification meas.

\begin{tabular}{lrrrrrr}
\hline Configuration & \multicolumn{1}{c}{ Op1 } & \multicolumn{1}{c}{ Op2 } & \multicolumn{1}{c}{ Op3 } & Op4 & Op5 & Op6 \\
\hline $0_{S S}$ & $98.9 \%$ & $100.8 \%$ & $100.2 \%$ & $102.4 \%$ & $102.0 \%$ & $103.8 \%$ \\
$4_{S S}$ & $100.4 \%$ & $99.4 \%$ & $99.7 \%$ & $101.5 \%$ & $102.2 \%$ & $102.8 \%$ \\
$8_{S S}$ & $102.5 \%$ & $99.6 \%$ & $99.9 \%$ & $100.5 \%$ & $99.7 \%$ & $100.2 \%$ \\
\hline
\end{tabular}

performance for different drive cycles can be investigated.

\section{FREQUENCY ANALYSIS}

Simulations of the operating points 1 and 6 are performed for configuration $0,1,4,5$ and 8 . Additionally, two mixtures, consisting of one half of a supercapacitor and one half of an electrolytic capacitor configuration, are considered. In Fig. 9 the harmonic spectrum of the battery pack voltage and current are shown for configuration 0 (pure battery) and configuration
4 (large electrolytic capacitor) at operating point 1. It should be noted that the capacitors suppress the harmonic content in the battery to a very large extent, lowering the second harmonic with a factor of about 4 for both, voltage and current. In TABLE IX, the harmonic content of the second, fourth and largest harmonic above $9 \mathrm{kHz}$ are shown. The supercapacitors show the greatest improvement of the harmonic content at operating point 1 due to the low frequency. At operating point 6 , the frequency is much higher. Therefore, the electrolytic capacitors show the best performance in terms of harmonic suppression.

From an EMI perspective, it is important to minimize the voltage swings/ripples in the DC cables and all 'conducting surfaces', since these are the sources for radiated emissions. The maximum amplitude at frequencies above $9 \mathrm{kHz}$ is significantly reduced for both types of capacitors at operating point 1, leading to an improved low frequency EMI situation. For operating point 6 , the electrolytic capacitors show the best improvement. In TABLE $X$, the second, fourth and sixth harmonic for the battery current are shown. There is a clear reduction of the current pulse stress on the battery. For the low speed operating point 1 , the second harmonic is best filtered with the supercapacitors due to its low frequency. The same tendency is also seen for the fourth and sixth harmonic, although less pronounced. At operating point 6 , the electrolytic capacitors show a better improvement for all harmonics due to the increased frequency at this operating point.

\section{DRIVE CyCle Operation}

Configurations 1-8 from TABLE IV and several mixtures of the two capacitor types are now used in simulations for the four drive cycles NEDC, FTP75, US06 and HWFET to be able to compare the performance. The battery current, capacitor current and voltage drop are shown in Fig. 10 for a short interval of the drive cycle HWFET at $\mathrm{t}=260 \mathrm{~s}$ for the configuration $0,4,8$ and a mix between $4 \& 8$. The weight and volume of configuration 4 and 8 are very similar (a bit more for the electrolytic case), but the relation between the resistance and the capacitance is very different between 

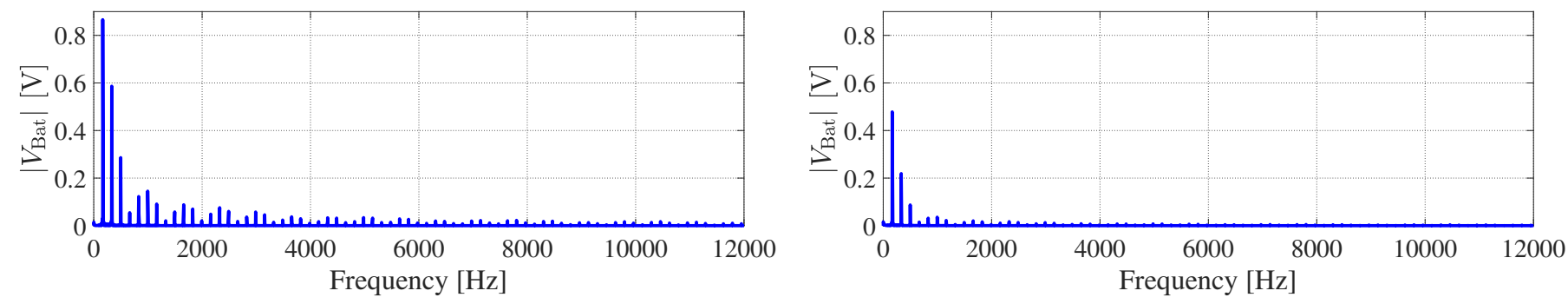

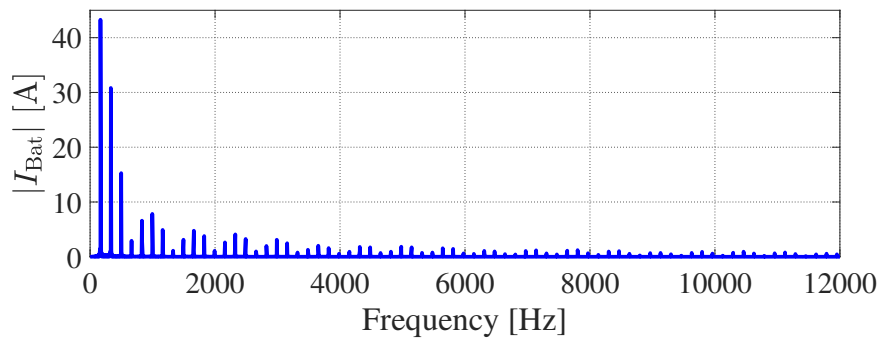

(a) Configuration 0

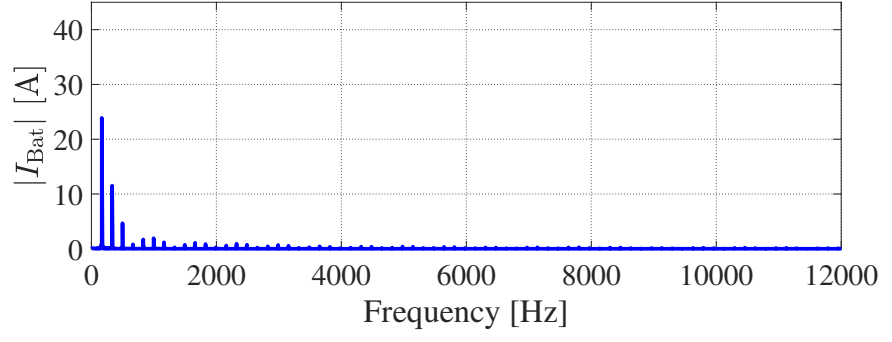

(b) Configuration 4

Fig. 9: Harmonic spectrum of the battery waveforms for operating point 1 for configurations (a) 0 and (b) 4 .

TABLE IX: Harmonic content of the battery pack voltage

\begin{tabular}{|c|c|c|c|c|c|c|c|}
\hline \multirow[t]{2}{*}{$\mathrm{OP}$} & Config. & \multicolumn{2}{|c|}{ 2nd harmonic } & \multicolumn{2}{|c|}{ 4th harmonic } & \multicolumn{2}{|c|}{ Highest above $9 \mathrm{kHz}$} \\
\hline & & $866 \mathrm{mV}$ & $100 \%$ & $586 \mathrm{mV}$ & $100 \%$ & $17 \mathrm{mV}$ & $100 \%$ \\
\hline & & $827 \mathrm{mV}$ & $95.5 \%$ & $529 \mathrm{mV}$ & $90.3 \%$ & $13 \mathrm{mV}$ & - \\
\hline & & $480 \mathrm{mV}$ & - & $223 \mathrm{mV}$ & - & $4 \mathrm{mV}$ & $23.6 \%$ \\
\hline \multirow[t]{7}{*}{ OP1 } & & $729 \mathrm{mV}$ & - & $505 \mathrm{mV}$ & - & $15 \mathrm{mV}$ & $88.24 \%$ \\
\hline & & $297 \mathrm{mV}$ & $34.3 \%$ & $211 \mathrm{mV}$ & $36.0 \%$ & $6 \mathrm{mV}$ & - \\
\hline & Mix 1 and 5 & $776 \mathrm{mV}$ & - & $518 \mathrm{mV}$ & - & $14 \mathrm{mV}$ & - \\
\hline & Mix 4 and 8 & $8 \quad 389 \mathrm{mV}$ & - & $229 \mathrm{mV}$ & - & $5 \mathrm{mV}$ & - \\
\hline & & $01179 \mathrm{mV}$ & $100 \%$ & $274 \mathrm{mV}$ & $100 \%$ & $30 \mathrm{mV}$ & $100 \%$ \\
\hline & & $634 \mathrm{mV}$ & - & $209 \mathrm{mV}$ & - & $23 \mathrm{mV}$ & - \\
\hline & & $194 \mathrm{mV}$ & $16.5 \%$ & $63 \mathrm{mV}$ & $23.9 \%$ & $7 \mathrm{mV}$ & $23.3 \%$ \\
\hline \multirow[t]{4}{*}{ OP6 } & & $714 \mathrm{mV}$ & $60.6 \%$ & $238 \mathrm{mV}$ & $86.9 \%$ & $27 \mathrm{mV}$ & $90.9 \%$ \\
\hline & & $302 \mathrm{mV}$ & - & $101 \mathrm{mV}$ & - & $11 \mathrm{mV}$ & - \\
\hline & Mix 1 and 5 & $672 \mathrm{mV}$ & - & $222 \mathrm{mV}$ & - & $25 \mathrm{mV}$ & - \\
\hline & Mix 4 and 8 & $8238 \mathrm{mV}$ & - & $78 \mathrm{mV}$ & - & $9 \mathrm{mV}$ & - \\
\hline
\end{tabular}

TABLE X: Harmonic content of the battery pack current

\begin{tabular}{|c|c|c|c|c|c|c|c|}
\hline \multirow[t]{2}{*}{ OP } & \multirow[t]{2}{*}{ Config. } & \multicolumn{2}{|c|}{ 2nd harmonic } & \multicolumn{2}{|c|}{ 4th harmonic } & \multicolumn{2}{|c|}{ 6th harmonic } \\
\hline & & $043 \mathrm{~A}$ & $100 \%$ & $31 \mathrm{~A}$ & $100 \%$ & $16 \mathrm{~A}$ & $100 \%$ \\
\hline & & $141 \mathrm{~A}$ & $95.3 \%$ & $28 \mathrm{~A}$ & $90.39 \%$ & $13 \mathrm{~A}$ & $81.3 \%$ \\
\hline & & $424 \mathrm{~A}$ & - & $12 \mathrm{~A}$ & - & $5 \mathrm{~A}$ & $31.3 \%$ \\
\hline \multirow[t]{7}{*}{ OP1 } & & $536 \mathrm{~A}$ & - & $27 \mathrm{~A}$ & - & $13 \mathrm{~A}$ & $81.3 \%$ \\
\hline & & $815 \mathrm{~A}$ & $34.9 \%$ & $11 \mathrm{~A}$ & $35.5 \%$ & $6 \mathrm{~A}$ & - \\
\hline & Mix 1 and 5 & $539 \mathrm{~A}$ & - & $27 \mathrm{~A}$ & - & $13 \mathrm{~A}$ & $81.3 \%$ \\
\hline & Mix 4 and 8 & $819 \mathrm{~A}$ & - & $12 \mathrm{~A}$ & - & $5 \mathrm{~A}$ & $31.3 \%$ \\
\hline & & $045 \mathrm{~A}$ & $100 \%$ & $15 \mathrm{~A}$ & $100 \%$ & $6 \mathrm{~A}$ & $100 \%$ \\
\hline & & $134 \mathrm{~A}$ & - & $11 \mathrm{~A}$ & - & $4 \mathrm{~A}$ & - \\
\hline & 4 & $410 \mathrm{~A}$ & $22.8 \%$ & $3 \mathrm{~A}$ & $20.0 \%$ & $1 \mathrm{~A}$ & $16.7 \%$ \\
\hline \multirow[t]{4}{*}{ OP6 } & & $539 \mathrm{~A}$ & $86.7 \%$ & $13 \mathrm{~A}$ & $86.7 \%$ & $5 \mathrm{~A}$ & $83.3 \%$ \\
\hline & & $816 \mathrm{~A}$ & - & $5 \mathrm{~A}$ & - & $2 \mathrm{~A}$ & - \\
\hline & Mix 1 and 5 & $536 \mathrm{~A}$ & - & $12 \mathrm{~A}$ & - & $5 \mathrm{~A}$ & $83.3 \%$ \\
\hline & Mix 4 and 8 & $813 \mathrm{~A}$ & - & $4 \mathrm{~A}$ & - & $2 \mathrm{~A}$ & - \\
\hline
\end{tabular}

the two chemistries. From the figure it can be seen that the electrolytic capacitor (configuration 4) has less resistance than the supercapacitor (configuration 8) and holds the voltage well in the first period of time after the current is applied. However, the capacitance is much lower in configuration 4 compared to configuration 8. After some hundreds of microseconds the voltage has dropped to a lower level than the supercapacitor.

Depending on the operating speed (frequency) of the car, the two chemistries clearly have different advantages. The total battery losses for the drive cycles are presented in Fig. 11. In general, it can be noted that a large decrease of battery losses occurs, if the capacitors are place at the input of the H-bridges of a multilevel inverter used in electrified vehicles.

The configurations with electrolytic capacitors (configuration 1-4) show slight lower losses compared to the configura- tions with supercapacitors (configurations 5-8), but they also weigh slightly more. With configurations 4 and 8 a reduction of the battery losses by about $40 \%$ is achieved. However, there is an added mass of about $5 \mathrm{~kg}$ per H-bridge module, which initially weighed $12.5 \mathrm{~kg}$ each. In Fig. 12 the battery loss reduction as a function of added weight is plotted. Adding capacitors is always an advantage, from a loss point of view, compared to adding more batteries for the four drive cycles, when considering the total weight of the storage system. For three of the four drive cycles it is most advantageous from a loss perspective to add a certain mass of electrolytic capacitors and for one of the four drive cycles it is most advantageous to add supercapacitors. Adding a mix of both capacitor types shows a similar effect, as the losses are at a level between the supercapacitor and the electrolytic capacitor cases. If the 

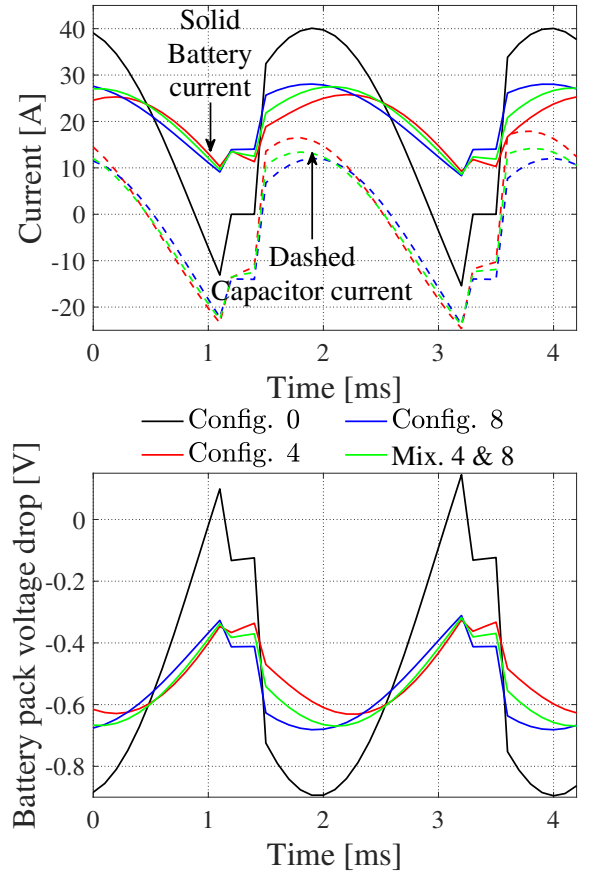

(a) $\alpha_{1}$ - Battery 1
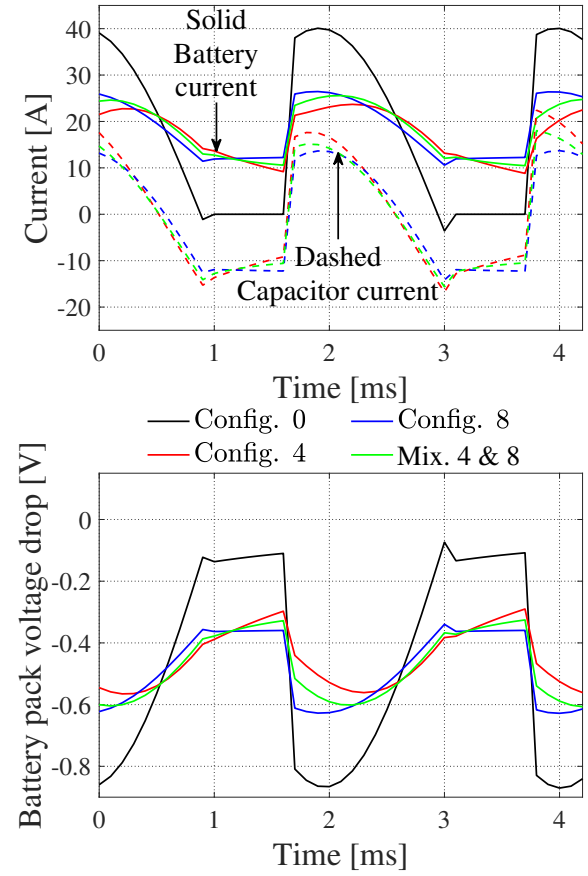

(b) $\alpha_{2}$ - Battery 2
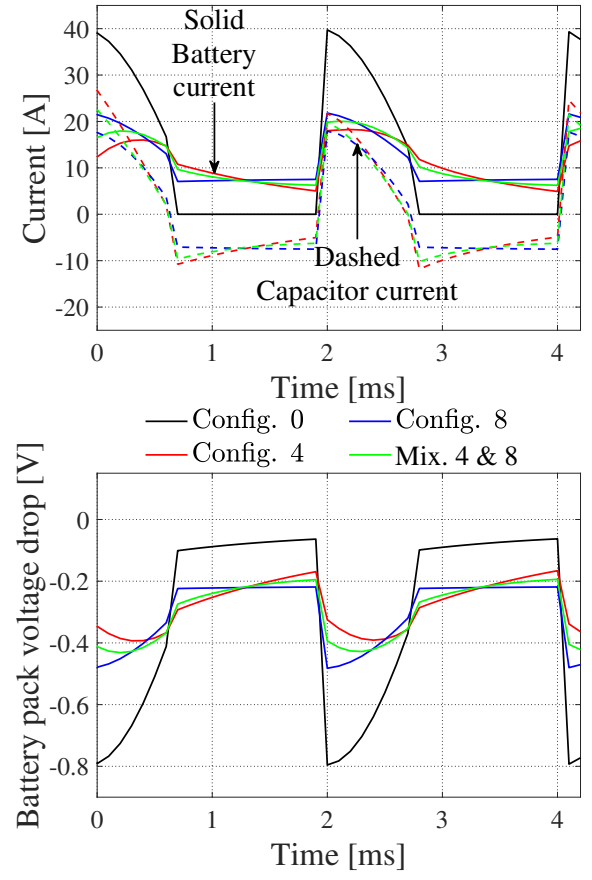

(c) $\alpha_{3}$ - Battery 3

Fig. 10: Battery performance during a short interval of the HWFET-drive cycle, if controlled with (a) $\alpha_{1}$,(b) $\alpha_{2}$ and (c) $\alpha_{3}$.

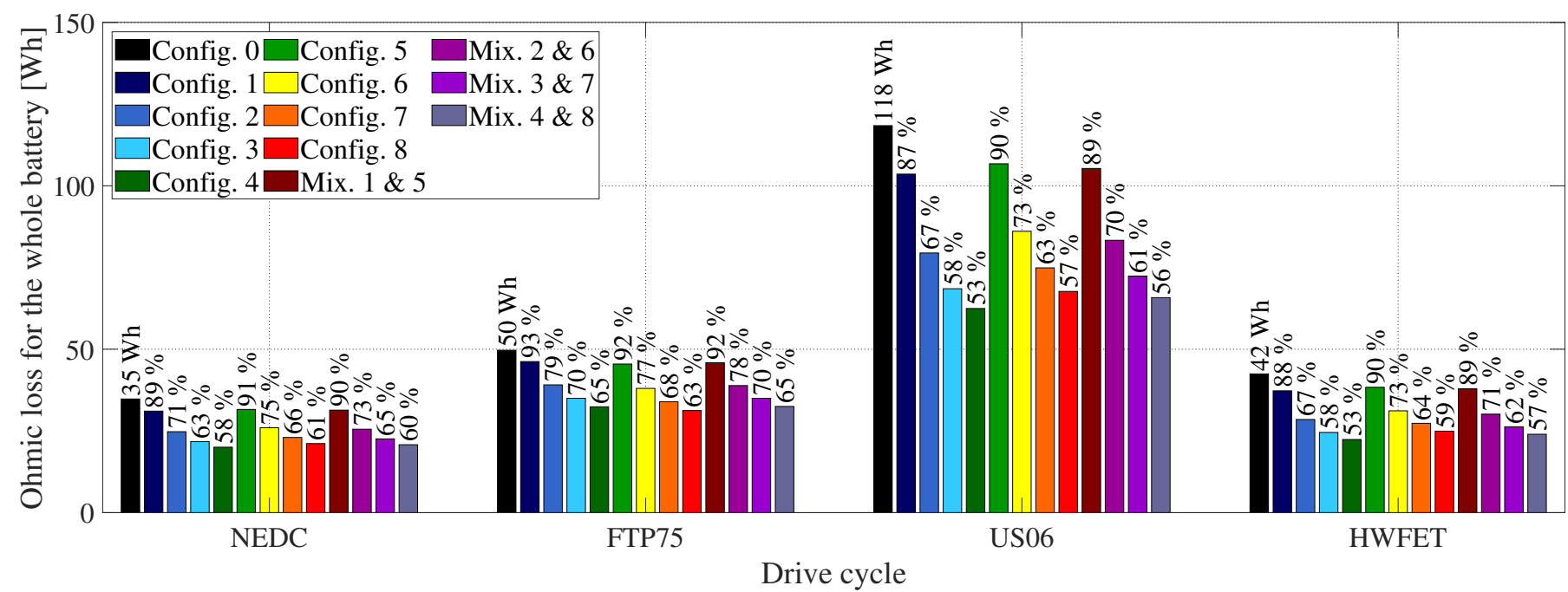

Fig. 11: Ohmic energy loss for the whole battery system for different drive cycles.

capacitors were instead replaced with more battery cells with a similar mass addition, the losses in the battery would also be lowered, however, to a lower extent.

Nevertheless, the reduction of the battery losses should be also assessed in comparison to the added cost per battery module. For this purpose, the high-volume costs for the capacitors and batteries are required. Since all additional cells or capacitors can be passively paralleled to the battery pack, it is sufficient to consider the prices on the cell level, excluding the costs for the packaging and the electronics. This linearized cost estimation is valid as long as the added weight does not significantly exceed the batteries initial weight, hence an additional mass of up to $50 \%$ is considered. From the literature, it can be seen that battery prices are constantly decreasing, while the current price is about $200 \$$ per $\mathrm{kWh}$ [51], [52]. The used battery cells have an energy density of about $108 \mathrm{Whkg}^{-1}$, which results in an estimated cost of about $21.6 \$$ per $\mathrm{kg}$. In comparison, according to [52], the cost of supercapacitors is about $10,000 \$$ per $\mathrm{kWh}$, which results in a relative cost of about $32.8 \$$ per $\mathrm{kg}$ for the chosen supercapacitors. The used electrolyte capacitor system was based on the peh169gd5220q capacitor from Kemet [53]. Considering the current high-volume price of the PEH169 and PEH200 capacitor series with respect to the energy density, results in a relative price of about $40.18 \$$ per $\mathrm{kg}$ [54]. Consequently, the added cost relative to the reduced battery losses can be 

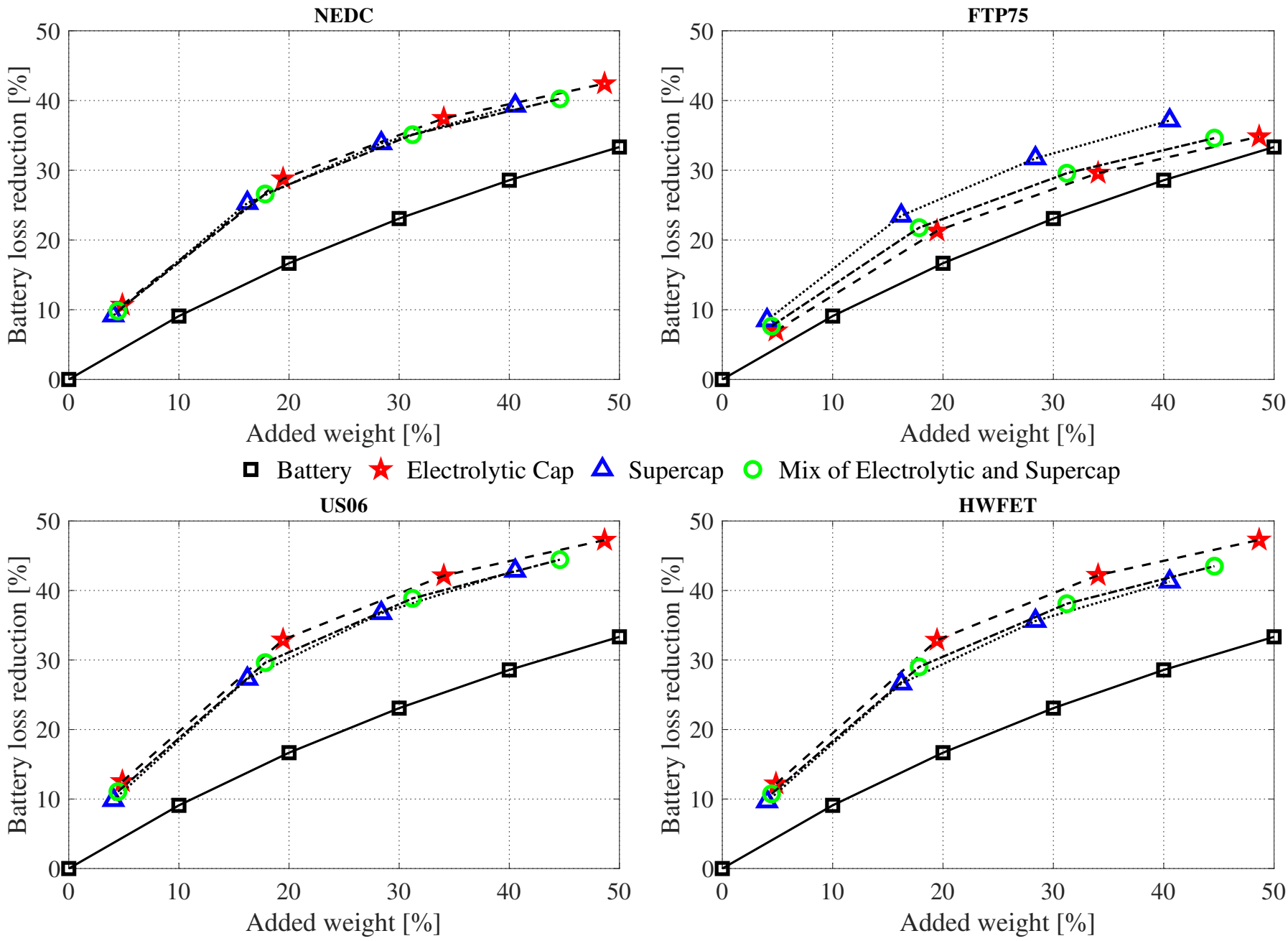

Fig. 12: Battery loss reduction for different mass of added filter capacitors.

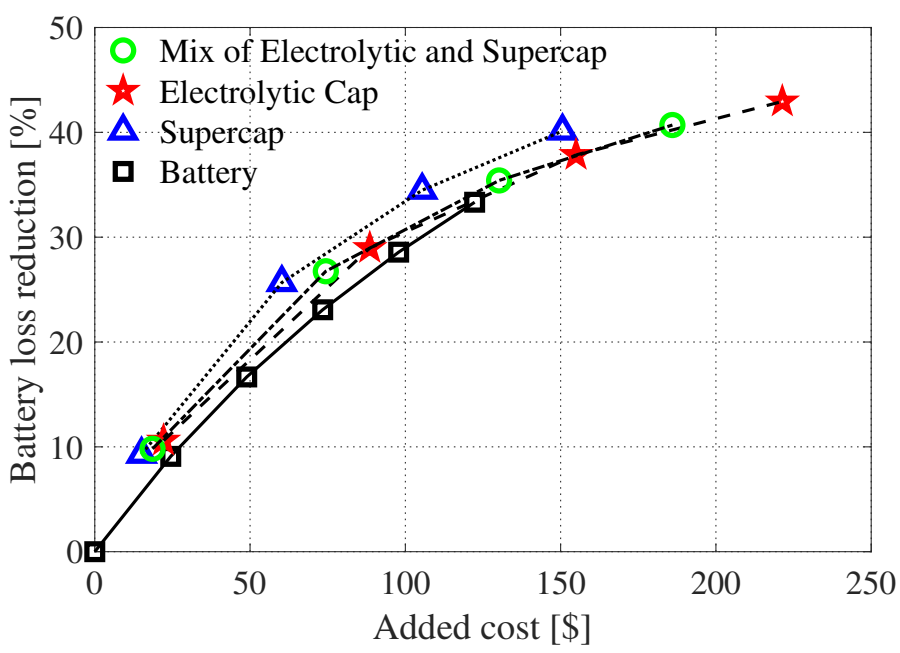

Fig. 13: Battery loss reduction for estimated cost of added filter capacitors.

calculated, as shown in Fig. 13, for the mean of all four driving cycles. It can be seen that an HESS of battery pack and supercapacitors is a cost-effective solution to optimize the chosen PHEV power train with respect to weight and system cost. Also, the electrolyte capacitors achieve an improvement regarding the system efficiency and the system costs, however, less than in comparison to the supercapacitors. Nonetheless, additional battery cells linearly increase the electric driving range of the vehicle, which is a great benefit. On the contrary, the filter capacitors reduce the size of the necessary EMI filters, which is not taken into account yet. Furthermore, the supercapacitors extend the lifetime of the battery system [52], which is neither considered yet.

\section{Cold Climate Performance}

The effect of the filter capacitors can be even more beneficial, if the impedance of the battery pack relative to the capacitor impedance is increased, as for example during winter weather conditions. Therefore, this section shortly emphasizes the improved loss reduction by the filter capacitors during cold climate. Only simulations are used for this analysis.

\section{A. Performance at Operating Points 1-6}

For a cold battery it is of utmost importance to avoid cyclings, since the life time loss is substantial, if the temperature 
TABLE XI: Battery performance in cold climate

\begin{tabular}{|c|c|c|c|c|c|c|}
\hline \multirow[b]{2}{*}{$\mathrm{OP}$} & \multirow[b]{2}{*}{ Config. } & \multirow[b]{2}{*}{ Losses } & \multirow[b]{2}{*}{ Relative losses } & \multicolumn{3}{|c|}{ Harmonics } \\
\hline & & & & $2 \mathrm{nd}$ & 4 th & 6 th \\
\hline \multirow{3}{*}{ OP1 } & 0 & $750 \mathrm{~W}$ & $100 \%$ & $43 \mathrm{~A}$ & $31 \mathrm{~A}$ & $16 \mathrm{~A}$ \\
\hline & 1 & $528 \mathrm{~W}$ & $70 \%$ & $32 \mathrm{~A}$ & $18 \mathrm{~A}$ & $8 \mathrm{~A}$ \\
\hline & 5 & $522 \mathrm{~W}$ & $70 \%$ & $24 \mathrm{~A}$ & $18 \mathrm{~A}$ & $9 \mathrm{~A}$ \\
\hline \multirow{3}{*}{$\mathrm{OP} 2$} & 0 & $2491 \mathrm{~W}$ & $100 \%$ & $83 \mathrm{~A}$ & $47 \mathrm{~A}$ & $13 \mathrm{~A}$ \\
\hline & 1 & $1862 \mathrm{~W}$ & $75 \%$ & $61 \mathrm{~A}$ & $27 \mathrm{~A}$ & $7 \mathrm{~A}$ \\
\hline & 5 & $1810 \mathrm{~W}$ & $73 \%$ & $46 \mathrm{~A}$ & $27 \mathrm{~A}$ & $8 \mathrm{~A}$ \\
\hline \multirow{3}{*}{ OP3 } & 0 & $5158 \mathrm{~W}$ & $100 \%$ & $117 \mathrm{~A}$ & $51 \mathrm{~A}$ & $24 \mathrm{~A}$ \\
\hline & 1 & $3968 \mathrm{~W}$ & $77 \%$ & $87 \mathrm{~A}$ & $29 \mathrm{~A}$ & $12 \mathrm{~A}$ \\
\hline & 5 & $3859 \mathrm{~W}$ & $75 \%$ & $65 \mathrm{~A}$ & $29 \mathrm{~A}$ & $13 \mathrm{~A}$ \\
\hline \multirow{3}{*}{ OP4 } & 0 & $3327 \mathrm{~W}$ & $100 \%$ & $56 \mathrm{~A}$ & $8 \mathrm{~A}$ & $12 \mathrm{~A}$ \\
\hline & 1 & $2377 \mathrm{~W}$ & $71 \%$ & $25 \mathrm{~A}$ & $3 \mathrm{~A}$ & $5 \mathrm{~A}$ \\
\hline & 5 & $2626 \mathrm{~W}$ & $79 \%$ & $32 \mathrm{~A}$ & $4 \mathrm{~A}$ & $7 \mathrm{~A}$ \\
\hline \multirow{3}{*}{ OP5 } & 0 & $11987 \mathrm{~W}$ & $100 \%$ & $108 \mathrm{~A}$ & $22 \mathrm{~A}$ & $10 \mathrm{~A}$ \\
\hline & 1 & $8871 \mathrm{~W}$ & $74 \%$ & $48 \mathrm{~A}$ & $9 \mathrm{~A}$ & $4 \mathrm{~A}$ \\
\hline & 5 & $9680 \mathrm{~W}$ & $81 \%$ & $62 \mathrm{~A}$ & $13 \mathrm{~A}$ & $6 \mathrm{~A}$ \\
\hline \multirow{3}{*}{ OP6 } & 0 & $9159 \mathrm{~W}$ & $100 \%$ & $45 \mathrm{~A}$ & $15 \mathrm{~A}$ & $6 \mathrm{~A}$ \\
\hline & 1 & $7534 \mathrm{~W}$ & $82 \%$ & $19 \mathrm{~A}$ & $6 \mathrm{~A}$ & $2 \mathrm{~A}$ \\
\hline & 5 & $7983 \mathrm{~W}$ & $87 \%$ & $26 \mathrm{~A}$ & $9 \mathrm{~A}$ & $3 \mathrm{~A}$ \\
\hline
\end{tabular}

goes to $0{ }^{\circ} \mathrm{C}$ or below [34]. At cold temperatures, the battery resistance increases, e.g. by about $400 \%$, if the temperature drops from $25^{\circ} \mathrm{C}$ to $0{ }^{\circ} \mathrm{C}$ [37]. The used capacitors do not increase their resistance by the same amount, roughly $20 \%$, for the same temperature drop [37]. Therefore, operating points 1-6 are simulated again, while the battery resistance is increased by $400 \%$ and the capacitor resistance is increased by $20 \%$. The resulting losses and battery output current harmonics for configuration 0 (pure battery), 1 (small electrolytic capacitors) and 5 (small supercapacitors) can be seen in TABLE XI. It can be seen that the loss in the battery system is substantial. For example, at OP5 the battery losses are about $12 \mathrm{~kW}$, while the mechanical output power is about $31.4 \mathrm{~kW}$. This results already in a decreased drive train efficiency of about $72.4 \%$, excluding motor and inverter losses. This high power dissipation indicates also that the possible driving range is substantially decreased. Nevertheless, the loss reduction, when using supporting capacitors, is significantly improved. Roughly, a 2.5 times greater reduction is achieved at $0{ }^{\circ} \mathrm{C}$ compared to $25^{\circ} \mathrm{C}$. It can also be observed, that the harmonic content is significantly reduced as well, by adding these small capacitors.

\section{CONCLUSION}

This paper investigated the influence of adding filter capacitors at the input of the $\mathrm{H}$-bridges in a cascaded $\mathrm{H}$-bridge multilevel inverter in an electrified vehicle application. The purpose is to lower the current stress on the battery and to decrease the battery losses. Therefore, this paper focused on two main aspects, the reduction of the low-order battery current and voltage harmonics and the enhancement of the battery drive cycle efficiency relative to the added weight and cost. A converted, small scale system was used to experimentally verify the assumptions and simulation results. Furthermore, the loss reduction during cold climate conditions was analyzed using simulations. Two different filter capacitor types were investigated: supercapacitors and electrolytic capacitors. It was seen that the low-order battery current and voltage harmonics can be substantially reduced by additional capacitors. Depending on the chosen amount of capacitance and the operating point of the drive train, the battery low-order current and voltage harmonics, as for example the second and the fourth harmonic, can be reduced by about $5 \%$ to $83.5 \%$. The drive cycle analysis showed that the battery losses are lowered, if filter capacitors are placed at the inputs of the Hbridges. A $4 \%$ addition of capacitors gives a loss reduction of $10 \%$ at a battery temperature of $25^{\circ} \mathrm{C}$. For a given mass of capacitors, the loss reduction is almost the same when using supercapacitors and electrolytic capacitors for the investigated vehicle system. However, considering also the system costs, an HESS of supercapacitors and battery is a cost-effective solution for the chosen PHEV powertrain. Furthermore, the simulated cold climate operation showed that the implementation of the capacitors at the input of the H-bridges relieves the battery stress and reduces the battery losses to a great extent, even for a small amount of capacitors. In the future, the reduction of the required EMI filters and the battery life time extension relative to the added weight and capacitance should be investigated. Furthermore, the used battery model could be used to determine an optimal modulation technique, depending on the load torque and speed. For example, Fundamental Selective Harmonic Elimination (FSHE) works very efficiently at high speeds, whereas space vector modulation is more suitable for low speeds [37]. Here, a challenge lies in an implementation of an online battery impedance spectroscopy, which is important, because of the battery parameter variation due to climate conditions and ageing.

\section{ACKNOWLEDGMENT}

The financial support provided by the Swedish Energy Agency is gratefully acknowledged.

\section{REFERENCES}

[1] L. M. Tolbert, F. Z. Peng, and T. G. Habetler, "Multilevel inverters for electric vehicle applications," in Power Electronics in Transportation (Cat. No.98TH8349), Oct 1998, pp. 79-84.

[2] Z. Du, L. M. Tolbert, J. N. Chiasson, B. Ozpineci, H. Li, and A. Q. Huang, "Hybrid cascaded h-bridges multilevel motor drive control for electric vehicles," in 2006 37th IEEE Power Electronics Specialists Conference, June 2006, pp. 1-6.

[3] O. Josefsson, A. Lindskog, S. Lundmark, and T. Thiringer, "Assessment of a multilevel converter for a phev charge and traction application," in The XIX International Conference on Electrical Machines - ICEM 2010, Sept 2010, pp. 1-6.

[4] S. H. Hosseini, M. Ahmadi, and S. Ghassem Zadeh, "Reducing the output harmonics of cascaded h-bridge multilevel inverter for electric vehicle applications," in The 8th Electrical Engineering/ Electronics, Computer, Telecommunications and Information Technology (ECTI) Association of Thailand - Conference 2011, May 2011, pp. 752-755.

[5] Y. Cho, T. LaBella, J. Lai, and M. K. Senesky, "A carrier-based neutral voltage modulation strategy for multilevel cascaded inverters under unbalanced dc sources," IEEE Transactions on Industrial Electronics, vol. 61, no. 2, pp. 625-636, Feb 2014. 
[6] L. Wang, D. Zhang, Y. Wang, B. Wu, and H. S. Athab, "Power and voltage balance control of a novel three-phase solid-state transformer using multilevel cascaded h-bridge inverters for microgrid applications,' IEEE Transactions on Power Electronics, vol. 31, no. 4, pp. 3289-3301, April 2016.

[7] R. Sajadi, H. Iman-Eini, M. K. Bakhshizadeh, Y. Neyshabouri, and S. Farhangi, "Selective harmonic elimination technique with control of capacitive dc-link voltages in an asymmetric cascaded h-bridge inverter for statcom application," IEEE Transactions on Industrial Electronics, vol. 65, no. 11, pp. 8788-8796, Nov 2018.

[8] J. Lee, K. Lee, and Y. Ko, "An improved phase-shifted pwm method for a three-phase cascaded h-bridge multi-level inverter," in 2017 IEEE Energy Conversion Congress and Exposition (ECCE), Oct 2017, pp. 2100-2105.

[9] E. Guan, P. Song, M. Ye, and B. Wu, "Selective harmonic elimination techniques for multilevel cascaded h-bridge inverters," in 2005 International Conference on Power Electronics and Drives Systems, vol. 2, Nov 2005, pp. 1441-1446.

[10] M. S. A. Dahidah and V. G. Agelidis, "Selective harmonic elimination multilevel converter control with variant dc sources," in 2009 4th IEEE Conference on Industrial Electronics and Applications, May 2009, pp. 3351-3356.

[11] H. Lou, C. Mao, D. Wang, J. Lu, and L. Wang, "Fundamental modulation strategy with selective harmonic elimination for multilevel inverters," IET Power Electronics, vol. 7, no. 8, pp. 2173-2181, August 2014.

[12] Z. Zheng, K. Wang, L. Xu, and Y. Li, "A hybrid cascaded multilevel converter for battery energy management applied in electric vehicles," IEEE Transactions on Power Electronics, vol. 29, no. 7, pp. 3537-3546, July 2014.

[13] A. Bessman, R. Soares, S. Vadivelu, O. Wallmark, P. Svens, H. Ekström, and G. Lindbergh, "Challenging sinusoidal ripple-current charging of lithium-ion batteries," IEEE Transactions on Industrial Electronics, vol. 65 , no. 6, pp. 4750-4757, June 2018 .

[14] M. Uno and K. Tanaka, "Influence of high-frequency charge-discharge cycling induced by cell voltage equalizers on the life performance of lithium-ion cells," IEEE Transactions on Vehicular Technology, vol. 60, no. 4, pp. 1505-1515, May 2011.

[15] M. Quraan, P. Tricoli, S. DâArco, and L. Piegari, "Efficiency assessment of modular multilevel converters for battery electric vehicles," IEEE Transactions on Power Electronics, vol. 32, no. 3, pp. 2041-2051, March 2017.

[16] A. Marzoughi, R. Burgos, D. Boroyevich, and Y. Xue, "Design and comparison of cascaded h-bridge, modular multilevel converter, and 5-1 active neutral point clamped topologies for motor drive applications,' IEEE Transactions on Industry Applications, vol. 54, no. 2, pp. 1404 1413, March 2018.

[17] P. Hothongkham and V. Kinnares, "Investigation into harmonic losses in a pwm multilevel cascaded h-bridge inverter fed induction motor," in 2007 7th International Conference on Power Electronics and Drive Systems, Nov 2007, pp. 1043-1048.

[18] A. Kersten, E. Grunditz, and T. Thiringer, "Efficiency of active threelevel and five-level npc inverters compared to a two-level inverter in a vehicle," in 2018 20th European Conference on Power Electronics and Applications (EPE'18 ECCE Europe), Sep. 2018, pp. P.1-P.9.

[19] A. Kersten, K. Oberdieck, A. Bubert, M. Neubert, E. Grunditz, T. Thiringer, and R. W. De Doncker, "Fault detection and localization for limp home functionality of three-level npc inverters with connected neutral point for electric vehicles," IEEE Transactions on Transportation Electrification, pp. 1-1, 2019.

[20] J. Cao and A. Emadi, "A new battery/ultracapacitor hybrid energy storage system for electric, hybrid, and plug-in hybrid electric vehicles," IEEE Transactions on Power Electronics, vol. 27, no. 1, pp. 122-132, Jan 2012.

[21] J. Shen and A. Khaligh, "A supervisory energy management control strategy in a battery/ultracapacitor hybrid energy storage system," IEEE Transactions on Transportation Electrification, vol. 1, no. 3, pp. 223231, Oct 2015.

[22] E. Chemali, M. Preindl, P. Malysz, and A. Emadi, "Electrochemical and electrostatic energy storage and management systems for electric drive vehicles: State-of-the-art review and future trends," IEEE Journal of Emerging and Selected Topics in Power Electronics, vol. 4, no. 3, pp. 1117-1134, Sep. 2016.

[23] A. Baumgardt and D. Gerling, "48v recuperation storage based on supercaps for automotive applications," EVS28, 2015.

[24] S. Lu, K. A. Corzine, and M. Ferdowsi, "A unique ultracapacitor direct integration scheme in multilevel motor drives for large vehicle propulsion," IEEE Transactions on Vehicular Technology, vol. 56, no. 4, pp. 1506-1515, July 2007.

[25] F. Ciccarelli, G. Clemente, and D. Iannuzzi, "Energy storage management control based on supercapacitors using a modular multilevel inverter topology for electrical vehicles," in 2013 International Conference on Clean Electrical Power (ICCEP), June 2013, pp. 170-176.

[26] F. Helling, M. Kuder, A. Singer, S. Schmid, and T. Weyh, "Low voltage power supply in modular multilevel converter based split battery systems for electrical vehicles," in 2018 20th European Conference on Power Electronics and Applications (EPE'18 ECCE Europe), Sep. 2018, pp. P.1-P.10.

[27] S. D'Arco, M. Quraan, P. Tricoli, and L. Piegari, "Low frequency operation of modular multilevel converters with embedded battery cells for traction drives," in 2016 International Symposium on Power Electronics, Electrical Drives, Automation and Motion (SPEEDAM), June 2016, pp. 1375-1382.

[28] L. A. Tolbert, F. Z. Peng, T. Cunnyngham, and J. N. Chiasson, "Charge balance control schemes for cascade multilevel converter in hybrid electric vehicles," IEEE Transactions on Industrial Electronics, vol. 49. no. 5, pp. 1058-1064, Oct 2002.

[29] A. Baumgardt, F. Bachheibl, A. Patzak, and D. Gerling, "48v traction: Innovative drive topology and battery," in 2016 IEEE International Conference on Power Electronics, Drives and Energy Systems (PEDES), Dec 2016, pp. 1-6.

[30] C. Shin, D. Kim, A. Ko, I. Won, Y. Kim, and C. Won, "The configuration of electric vehicle system using isolated dc-dc converter for a low-voltage and high-current type battery," in 2015 9th International Conference on Power Electronics and ECCE Asia (ICPE-ECCE Asia), June 2015, pp. 2796-2801.

[31] Q. Liu, S. Wang, A. C. Baisden, F. Wang, and D. Boroyevich, "Emi suppression in voltage source converters by utilizing dc-link decoupling capacitors," IEEE Transactions on Power Electronics, vol. 22, no. 4, pp. 1417-1428, July 2007.

[32] General Administration of Quality Supervision, "Gb/t 18387-2008: Limits and test method of electric and magnetic field strength from electric vehicles, $9 \mathrm{kHz}$ to $30 \mathrm{MHz}$," National Standard of the people's republic of China, China, Standard, 2008.

[33] International Special Committee on Radio Interference (CISPR), "Vehicles, boats and internal combustion engines - radio disturbance characteristics - limits and methods of measurement for the protection of on-board receivers," CISPR 25:2016, IEC, Standard,, 2016.

[34] Z. Lei, C. Zhang, and J. Li, "Research on the low performance of power lithium-ion battery in electric vehicle," in 2014 IEEE Conference and Expo Transportation Electrification Asia-Pacific (ITEC Asia-Pacific), Aug 2014, pp. 1-5.

[35] Y. Shang, B. Xia, N. Cui, C. Zhang, and C. C. Mi, "An automotive onboard ac heater without external power supplies for lithium-ion batteries at low temperatures," IEEE Transactions on Power Electronics, vol. 33, no. 9, pp. 7759-7769, Sept 2018.

[36] S. Mohan, Y. Kim, and A. G. Stefanopoulou, "Energy-conscious warmup of li-ion cells from subzero temperatures," IEEE Transactions on Industrial Electronics, vol. 63, no. 5, pp. 2954-2964, May 2016.

[37] O. Josefsson, Investigation of a Multilevel Inverter for Electric Vehicle Applications, Doctoral Thesis at Chalmers University of Technology, Division of Electric Power Engineering, Gothenburg, 2015.

[38] E. Grunditz, Design and Assessment of Battery Electric Vehicle Powertrain, with Respect to Performance, Energy Consumption and Electric Motor Thermal Capability, Doctoral Thesis at Chalmers University of Technology, Division of Electric Power Engineering, Gothenburg, 2016.

[39] A123 Systems, High Power Lithium Ion ANR26650M1A, mD100001-02 datasheet, 2009-2010.

[40] R. C. Kroeze and P. T. Krein, "Electrical battery model for use in dynamic electric vehicle simulations," in 2008 IEEE Power Electronics Specialists Conference, June 2008, pp. 1336-1342.

[41] Y. Cao, R. C. Kroeze, and P. T. Krein, "Multi-timescale parametric electrical battery model for use in dynamic electric vehicle simulations,' IEEE Transactions on Transportation Electrification, vol. 2, no. 4, pp. 432-442, Dec 2016.

[42] A. Fotouhi, D. J. Auger, K. Propp, and S. Longo, "Accuracy versus simplicity in online battery model identification," IEEE Transactions on Systems, Man, and Cybernetics: Systems, vol. 48, no. 2, pp. 195-206, Feb 2018

[43] S. Skoog and S. David, "Parameterization of linear equivalent circuit models over wide temperature and soc spans for automotive lithium-ion cells using electrochemical impedance spectroscopy," Journal of Energy Storage, vol. 14, pp. 39-48, 2017. 
[44] S. Skoog, "Parameterization of equivalent circuit models for high power lithium-ion batteries in hev applications," in 2016 18th European Conference on Power Electronics and Applications (EPE'16 ECCE Europe), Sep. 2016, pp. 1-10.

[45] Y. Deng, Y. Wang, K. H. Teo, and R. G. Harley, "A simplified space vector modulation scheme for multilevel converters," IEEE Transactions on Power Electronics, vol. 31, no. 3, pp. 1873-1886, March 2016.

[46] Y. Deng and R. G. Harley, "Space-vector versus nearest-level pulse width modulation for multilevel converters," IEEE Transactions on Power Electronics, vol. 30, no. 6, pp. 2962-2974, June 2015.

[47] W. Yao, H. Hu, and Z. Lu, "Comparisons of space-vector modulation and carrier-based modulation of multilevel inverter," IEEE Transactions on Power Electronics, vol. 23, no. 1, pp. 45-51, Jan 2008.

[48] P. Kurzweil and M. Shamonin, "State-of-charge monitoring by impedance spectroscopy during long-term self-discharge of supercapacitors and lithium-ion batteries," Batteries, vol. 4, no. 3, p. 35, 2018.

[49] A. Demircal,, P. Sergeant, S. Koroglu, S. Kesler, E. Öztürk, and M. Tumbek, "Influence of the temperature on energy management in battery-ultracapacitor electric vehicles," Journal of cleaner production, vol. 176, pp. 716-725, 2018.

[50] V. Schwarzer and R. Ghorbani, "Drive cycle generation for design optimization of electric vehicles," IEEE Transactions on Vehicular Technology, vol. 62, no. 1, pp. 89-97, Jan 2013.

[51] DoE, US, "Cost and price metrics for automotive lithium-ion batteries," Office of Energy Efficiency and Renewable Energy, 2017.

[52] J. Libich, J. Máca, J. Vondrák, O. Čech, and M. Sedlaříková, "Supercapacitors: Properties and applications," Journal of Energy Storage, vol. 17, pp. 224-227, 2018.

[53] Electronic Components Kemet, "Datasheet - Screw Terminal Aluminum Electrolytic Capacitors PEH169 Series,", https://content.kemet.com/ datasheets/KEM_A4038_PEH169_105C.pdf, (Accessed on 01/29/2019).

[54] Premier Farnell LTD, "PEH200HT6220MU2 KEMET - Electrolytic Capacitor 0.22F," https://de.farnell.com/kemet/peh200ht6220mu2/ kondensator-0-22f-25v-alu-elko/dp/1679505?ost=PEH200HT6220M\& ddkey=https\%3Ade-DE\%2FElement14_Germany\%2Fsearch, (Accessed on $01 / 27 / 2019$ ).

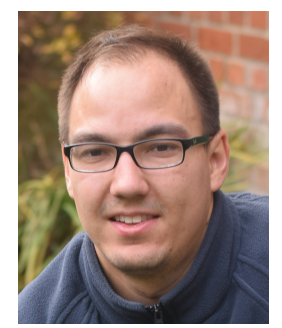

Anton Kersten (S'17) received the B.Eng. and the M.Sc. degree in electrical engineering with a major in electric power engineering from the University of Applied Science RheinMain in 2015 and the University of Technology Chalmers in 2017, respectively. Since October 2017 he is with the division of electric power engineering working within the field of multilevel inverter for vehicles' powertrain, while he is pursuing the Ph.D. degree.

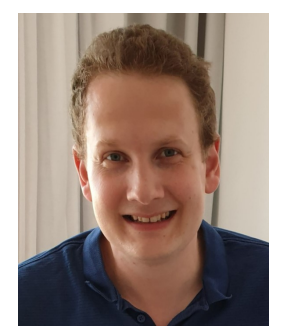

Oskar Theliander received the M.Sc. degree in electrical engineering, with a major in system controls and mechatronics, and the Ph.D. degree in electric power engineering from the University of Technology Chalmers, Gothenburg, Sweden, in 2009 and 2015, respectively. Since 2015 he is with Aaros Electronics $\mathrm{AB}$, where he works within the field of power electronics and drives for automotive applications.

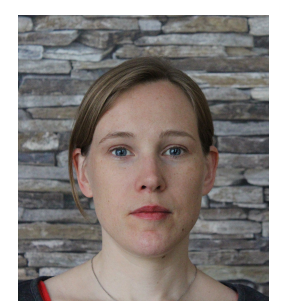

Emma Arfa Grunditz received her M.Sc. degree in 2009 and her Ph.D. degree in 2016 at Chalmers University of Technology, Gothenburg, Sweden, where she currently works as a post-doc researcher. Her research interests include electric drive systems, mainly for vehicular applications, regarding component and system cooling, energy consumption, performance and cost.

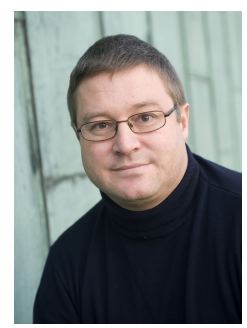

Torbjörn Thiringer (SM'10) received the M.S. and Ph.D. degrees from the Chalmers University of Technology, Gothenburg, Sweden, in 1989 and 1996, respectively. $\mathrm{He}$ is currently a Professor in applied power electronics with the Chalmers University of Technology. His current research interests include the modeling, control and grid integration of wind energy converters into power grids as well as power electronics, and drives for automotive and industry applications.

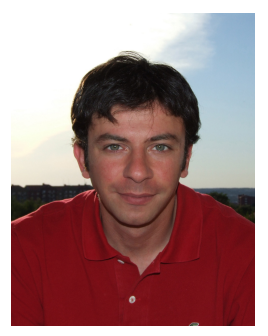

Massimo Bongiorno (SM'16) received the M.Sc. degree in electrical engineering from the University of Palermo, Palermo, Italy, in April 2002, and the Lic.Eng. and Ph.D. degree from the Chalmers University of Technology, Gothenburg, Sweden, in December 2004 and September 2007, respectively. From 2007 to 2010, he was an Assistant Professor at the Department of Electric Power Engineering, Chalmers University of Technology, where he became an Associate Professor in 2010. Since 2015, he has been holding the position of Professor in power electronic applications for power systems. His research interests include application of power electronics in power systems, power system dynamics, and power quality. 